\title{
Impacts of global open-fire aerosols on direct radiative, cloud and surface-albedo effects simulated with CAM5
}

\author{
Yiquan Jiang ${ }^{1,2}$, Zheng Lu $^{2}$, Xiaohong Liu ${ }^{2}$, Yun Qian ${ }^{3}$, Kai Zhang ${ }^{3}$, Yuhang Wang ${ }^{4}$, and Xiu-Qun Yang ${ }^{1}$ \\ ${ }^{1}$ CMA-NJU Joint Laboratory for Climate Prediction Studies, Institute for Climate and Global Change Research, \\ School of Atmospheric Sciences, Nanjing University, Nanjing, China \\ ${ }^{2}$ Department of Atmospheric Science, University of Wyoming, Laramie, Wyoming, USA \\ ${ }^{3}$ Pacific Northwest National Laboratory, Richland, Washington, USA \\ ${ }^{4}$ School of Earth and Atmospheric Sciences, Georgia Institute of Technology, Atlanta, Georgia, USA
}

Correspondence to: Xiaohong Liu (xliu6@uwyo.edu)

Received: 24 February 2016 - Published in Atmos. Chem. Phys. Discuss.: 1 April 2016

Revised: 30 October 2016 - Accepted: 8 November 2016 - Published: 29 November 2016

\begin{abstract}
Aerosols from open-land fires could significantly perturb the global radiation balance and induce climate change. In this study, Community Atmosphere Model version 5 (CAM5) with prescribed daily fire aerosol emissions is used to investigate the spatial and seasonal characteristics of radiative effects (REs, relative to the case of no fires) of open-fire aerosols including black carbon (BC) and particulate organic matter (POM) from 2003 to 2011. The global annual mean RE from aerosol-radiation interactions (REari) of all fire aerosols is $0.16 \pm 0.01 \mathrm{~W} \mathrm{~m}^{-2}$ ( $1 \sigma$ uncertainty), mainly due to the absorption of fire BC $\left(0.25 \pm 0.01 \mathrm{~W} \mathrm{~m}^{-2}\right)$, while fire POM induces a small effect $\left(-0.05\right.$ and $0.04 \pm 0.01 \mathrm{~W} \mathrm{~m}^{-2}$ based on two different methods). Strong positive REari is found in the Arctic and in the oceanic regions west of southern Africa and South America as a result of amplified absorption of fire BC above low-level clouds, in general agreement with satellite observations. The global annual mean RE due to aerosol-cloud interactions (REaci) of all fire aerosols is $-0.70 \pm 0.05 \mathrm{~W} \mathrm{~m}^{-2}$, resulting mainly from the fire POM effect $\left(-0.59 \pm 0.03 \mathrm{~W} \mathrm{~m}^{-2}\right)$. REari $\left(0.43 \pm 0.03 \mathrm{~W} \mathrm{~m}^{-2}\right)$ and REaci $\left(-1.38 \pm 0.23 \mathrm{~W} \mathrm{~m}^{-2}\right)$ in the Arctic are stronger than in the tropics $\left(0.17 \pm 0.02\right.$ and $-0.82 \pm 0.09 \mathrm{~W} \mathrm{~m}^{-2}$ for REari and REaci), although the fire aerosol burden is higher in the tropics. The large cloud liquid water path over land areas and low solar zenith angle of the Arctic favor the strong fire aerosol REaci (up to $-15 \mathrm{~W} \mathrm{~m}^{-2}$ ) during the Arctic summer. Significant surface cooling, precipitation reduction and increasing amounts of low-level cloud are also found
\end{abstract}

in the Arctic summer as a result of the fire aerosol REaci based on the atmosphere-only simulations. The global annual mean RE due to surface-albedo changes (REsac) over land areas $\left(0.03 \pm 0.10 \mathrm{~W} \mathrm{~m}^{-2}\right)$ is small and statistically insignificant and is mainly due to the fire BC-in-snow effect $\left(0.02 \mathrm{~W} \mathrm{~m}^{-2}\right)$ with the maximum albedo effect occurring in spring $\left(0.12 \mathrm{~W} \mathrm{~m}^{-2}\right)$ when snow starts to melt.

\section{Introduction}

Open fires or biomass burning of living and dead vegetation are an integral component of the Earth's system and have significant impacts on the carbon cycle (Ciais et al., 2013) and the climate (Bowman et al., 2009; Keywood et al., 2011; Liu et al., 2014; Sommers et al., 2014; Voulgarakis and Field, 2015). On one hand, open fires can perturb the climate system by emitting greenhouse gases and aerosols (Kaiser et al., 2012; Wiedinmyer et al., 2011). On the other hand, climate states and variabilities can play a critical role in determining the occurrence frequency and intensity of open fires (Marlon et al., 2009; van der Werf et al., 2008; Westerling et al., 2006; Bistinas et al., 2014). However, much is unknown regarding the feedback mechanisms between open fire and climate interactions (Carslaw et al., 2010; Liu et al., 2014). A qualification of radiative forcing of fire aerosols as conducted in this study is the first step to reducing these uncertainties.

Particles emitted from open fires can exert significant perturbations to the climate system by scattering and absorbing 
the solar radiation in the atmosphere (direct effect) (Carslaw et al., 2010) and by changing the surface albedo when they are deposited on the snow and ice (surface-albedo effect) (Flanner et al., 2007; Quinn et al., 2008; Randerson et al., 2006; Qian et al., 2011, 2015). In addition, open fire or smoke particles can modify the cloud properties, precipitation efficiency and the hydrological cycle by changing the atmospheric thermal structure (semi-direct effect) (Koch and Del Genio, 2010; Andreae et al., 2004) or acting as cloud condensation nuclei (CCN) (indirect effects) (Andreae and Rosenfeld, 2008; Qian et al., 2009; Lu and Sokolik, 2013).

The radiative effect (RE) (Boucher and Tanré, 2000) and radiative forcing (RF) (Forster et al., 2007; Myhre et al., 2013a) are typical metrics used to assess and compare anthropogenic and natural drivers of climate change. The aerosol RE represents the instantaneous radiative impact of atmospheric particles on the Earth's energy balance (Heald et al., 2014). RF is calculated as the change of RE between two different periods, e.g., the pre-industrial and the presentday times (Heald et al., 2014; Liu et al., 2007), based on the aerosol and precursor gas emissions in the two periods (Dentener et al., 2006; Lamarque et al., 2010).

RF from aerosol-radiation interactions (RFari) involving biomass burning aerosols has been estimated since the IPCC second Assessment Report (AR2). Based on the Aerosol Comparisons between Observations and Models (AeroCom) Phase II simulations (Bond et al., 2013; Myhre et al., 2013b), RFari of biomass burning aerosols in the IPCC Fifth Assessment Report (AR5) is estimated to be $0.0 \mathrm{~W} \mathrm{~m}^{-2}$ (ranging from -0.20 to $0.20 \mathrm{~W} \mathrm{~m}^{-2}$ ), and the RFari of biomass burning black carbon (BC) and primary organic matter (POM) have values with opposite signs (i.e., 0.10 and $-0.10 \mathrm{~W} \mathrm{~m}^{-2}$, respectively).

There are also some studies that estimated the RE from aerosol-radiation interactions (REari) involving fire aerosols by comparing the simulation with fire emissions to the simulation with no fire emissions. For example, using the NCAR Community Atmosphere Model version 4 (CAM4) with a bulk aerosol module, Tosca et al. (2013) reported that the top-of-atmosphere (TOA) REari from global biomass burning aerosols is $0.18 \pm 0.10 \mathrm{~W} \mathrm{~m}^{-2}$, averaged for the period of 1997-2009. Ward et al. (2012) estimated the REari from biomass burning aerosols in the pre-industrial (for the year 1850), present-day (for the year 2000) and future time periods (for the year 2100), and found that the biomass burning aerosol REari for the year 2000 is 0.13 and $-0.27 \mathrm{~W} \mathrm{~m}^{-2}$ for all-sky and clear-sky conditions, respectively.

RE from aerosol-cloud interactions (REaci) of biomass burning aerosols can be comparable in magnitude or of an even stronger magnitude than the REari (Liu et al., 2014). With a global aerosol-climate model, the REaci of biomass burning aerosols was estimated to range from -1.74 to $-1.00 \mathrm{~W} \mathrm{~m}^{-2}$ for the year 2000 in Ward et al. (2012). The semi-direct radiative effect of biomass burning aerosols is not independently assessed in IPCC reports. The magnitude was reported to be about $7.0 \mathrm{~W} \mathrm{~m}^{-2}$ in the southern American biomass burning regions by examining the radiative flux difference with and without the biomass burning aerosol effect on clouds (Liu, 2005).

The RF or RE due to surface-albedo changes (RFsac or REsac) of BC from open fires and other sources has been estimated in previous studies. For biomass burning emissions with a strong (1998) and weak (2001) boreal fire year, RE of fire BC-in-snow was estimated to be 0.011 and $0.006 \mathrm{~W} \mathrm{~m}^{-2}$, respectively (Flanner et al., 2007). Randerson et al. (2006) reported that $\mathrm{BC}$ from a boreal forest fire deposited on snow and sea ice introduced a global annual mean RE of $8 \pm 5 \mathrm{~W} \mathrm{~m}^{-2}$ of burned area in the first year when the fire happened. A summary of BC-in-snow forcing/effect can be found in Bond et al. (2013). They reported that the presentday RE of fire $\mathrm{BC}$-in-snow ranges from 0.006 to $0.02 \mathrm{~W} \mathrm{~m}^{-2}$ based on previous studies (Jacobson, 2004; Rypdal et al., 2009; Skeie et al., 2011; Hansen et al., 2005; Flanner et al., 2007, 2009; Koch et al., 2009).

Biomass burning aerosols can have significant impacts on global and regional precipitation and atmospheric circulation. With the change of fire emissions from 1860 to 2000, Jones et al. (2007) found that biomass burning aerosols decrease the global near-surface air temperature by about $0.25{ }^{\circ} \mathrm{C}$ when considering the feedbacks of sea surface temperature (SST) in the model. As shown in Tosca et al. (2013), the direct and semi-direct effects of biomass burning aerosols reduce the precipitation near the equator and weaken the Hadley circulation. With a regional climate model, Zhang et al. (2009) found that biomass burning aerosols may warm and stabilize the lower troposphere and thus reinforce the dry season rainfall pattern in southern Amazonia. The absorption of shortwave radiation by biomass burning $\mathrm{BC}$ could increase the vertical stratification and inhibit both the cloud formation and precipitation (Ackerman et al., 2000; Tosca et al., 2014). In contrast, biomass burning aerosols could invigorate the convective clouds (Andreae et al., 2004; Koren et al., 2005) through suppressing warm rain processes in the convection and enhance the latent heat release at higher levels (Andreae and Rosenfeld, 2008).

Although there have been many studies quantifying the $\mathrm{RE}$ of fire aerosols, further investigation is still needed as the current estimations of fire aerosol RE are still associated with large uncertainties (e.g., Myhre and Samset, 2015; Chakrabarty et al., 2014). The REs of co-emitted fire POM vs. BC are even less clear. In this study, we estimate the present day (from 2003 to 2011) open-fire aerosol REs (including REari, REaci and REsac) using the NCAR Community Atmosphere Model version 5.3 (CAM5) with the 4mode version of the modal aerosol module (MAM4). We use two methods to calculate the REari of fire aerosols (total, BC only and POM only). One method estimates the REari based on different model simulations (Ghan, 2013), and the other one calculates the REari directly through multiple diagnostic radiation calls in a single simulation. The spatial and sea- 
sonal characteristics of fire aerosol REs, and the impacts on the global precipitation and temperature are discussed.

Compared to earlier studies of fire aerosol REs (Tosca et al., 2013; Ward et al., 2012), a number of improvements are made in this study. First, a higher model horizontal resolution at $0.9^{\circ}$ by $1.25^{\circ}$ is used vs. $1.9^{\circ}$ by $2.5^{\circ}$. The higher resolution allows for more efficient transport of aerosols from the sources to remote regions (Ma et al., 2013, 2014). Model resolution has also been shown to be important for aerosol REaci (Ma et al., 2015). Second, the latest CAM5 model with MAM4 is used. MAM4 with an additional primary carbon mode explicitly treats the microphysical aging of primary carbonaceous aerosols (POM/BC) in the atmosphere. MAM4 has higher $\mathrm{BC}$ and $\mathrm{POM}$ burdens over the earlier 3-mode version of MAM (MAM3) in the remote regions by $\sim 30 \%$ (Liu et al., 2016). Third, daily instead of monthly fire emissions are used, which allows the model to consider the effect of fast changes in the fire emission flux on local atmospheric conditions. It is expected that, using the monthly mean emission flux, the model cannot consider the effect of extremely strong fires, thus it might underestimate the fire aerosol REs for such cases. Finally, a new methodology (Ghan, 2013) is used to more accurately diagnose the REs of fire aerosols. Central to this method is that the REari must be calculated in the presence of clouds (i.e., under the all-sky condition), and the REaci must be calculated under the condition of no aerosol effects on radiation. With the radiative forcing decomposition of this method, REsac can also be quantified.

The paper is organized as follows. Section 2 introduces the model and experiments. Section 3 describes the methods of diagnosing the fire aerosol REs. Section 4 presents the model results of fire aerosol REs and impacts on global and regional surface temperature and precipitation. Conclusions and discussion are given in Sect. 5.

\section{Model, experimental design and aerosol radiative effect method}

\subsection{Model}

In our study, we use the Community Earth System Model (CESM) version 1.2, with the Community Atmosphere Model version 5.3 (CAM5.3) (Neale et al., 2012) coupled with the Community Land Model version 4 (CLM4) (Oleson et al., 2010). The Snow, Ice, and Aerosol Radiative model (SNICAR) (Flanner and Zender, 2005) is turned on in the simulations to diagnose the biomass burning BC-in-snow effect. CAM5 includes several major updates in its physics parameterizations compared to previous CAM versions. A twomoment stratiform cloud microphysics scheme is included in CAM5 to predict both the mass and number mixing ratios of cloud liquid and cloud ice (Morrison and Gettelman, 2008). MAM4, which was updated from MAM3 (Liu et al., 2012), includes aerosol mass and number mixing ratios in four lognormal modes: Aitken, accumulation, coarse and primary carbon mode (Liu et al., 2016). An additional primary carbon mode is included in MAM4 on the top of MAM3 to explicitly treat the microphysical aging of primary carbonaceous aerosols (POM and BC) in the atmosphere. POM and $\mathrm{BC}$ in MAM4 are emitted in the primary carbon mode instead of directly in the accumulation mode as in MAM3. MAM4 significantly increases the $\mathrm{BC}$ and POM concentrations in the remote regions (e.g., over oceans and the Arctic) due to reduced wet scavenging of POM and BC in the primary carbon mode with a lower hygroscopicity than in the accumulation mode. The increase is relatively small in the land source regions (Liu et al., 2016).

\subsection{Experimental design}

CAM5 was run with the finite volume dynamics core in a resolution of $0.9^{\circ}$ latitude by $1.25^{\circ}$ longitude and 30 vertical levels. The model was run for the time period of year 2003 to 2011 (i.e., for 9 years) with prescribed monthly SST and sea ice. The year 2003 was run twice and the first year simulation was used as a model spin-up. Global Fire Emissions Database version 3.1 (GFED 3.1) daily emissions (Giglio et al., 2013) for BC, POM and sulfur dioxide $\left(\mathrm{SO}_{2}\right)$ from 2003 to 2011 are prescribed, and the vertical distribution of fire emissions is based on the AeroCom protocol (Dentener et al., 2006). Anthropogenic aerosol and precursor gas emissions are from the IPCC AR5 data set (Lamarque et al., 2010). We performed our control experiment (FIRE) with the GFED fire emissions turned on and a sensitivity experiment (NOFIRE) with the fire emissions turned off. Differences between FIRE and NOFIRE experiments are used to calculate the REs and atmospheric effects of biomass burning aerosols on temperature and precipitation. Two additional experiments, NOFIREBC and NOFIREPOM, were respectively performed with fire BC and POM emissions turned off. Differences between the control (FIRE) and these two experiments represent the contributions from biomass burning of BC and POM. Other forcings (e.g., SST, greenhouse gases) of all these experiments are kept the same. We performed ten ensemble members for each of these experiments. Furthermore, we performed the other experiment (FIRE_BBFFBF) using the modified CAM5 model that separately predicts the $\mathrm{BC}$ and POM from biomass burning (BB), fossil fuel (FF) and biofuel (BF) sources, while other model features are kept the same as the FIRE experiment. A summary of all the experiments in this study can be found in Table 1 .

\subsection{Methods of calculating fire aerosol radiative effects}

The REs of all fire aerosols, fire BC and fire POM are calculated from the differences in TOA shortwave fluxes $(\Delta F)$ between the FIRE experiment and the three other experiments (NOFIRE, NOFIREBC and NOFIREPOM, respectively). All the atmospheric variables (including temperature, 
Table 1. Numerical experiments and associated fire aerosol emissions in each experiment.

\begin{tabular}{lrlll}
\hline Experiment & Ensembles & $\begin{array}{l}\text { Fire } \\
\mathrm{BC}\end{array}$ & $\begin{array}{l}\text { Fire } \\
\mathrm{POM}\end{array}$ & $\begin{array}{l}\text { Fire } \\
\mathrm{SO}_{2}\end{array}$ \\
\hline FIRE & 10 & On & On & On \\
NOFIRE & 10 & Off & Off & Off \\
NOFIREBC & 10 & Off & On & On \\
NOFIREPOM & 10 & On & Off & On \\
FIRE_BBFFBF & 1 & On & On & On \\
\hline
\end{tabular}

precipitation and circulation) are allowed to adjust in the experiments. However, with SST and sea ice prescribed in these experiments, only the rapid adjustments are taken into account. Thus, the effective radiative effects are actually calculated in this study.

$\Delta F_{\text {fire aero }}=F_{\text {fire }}-F_{\text {nofire }}$

$\Delta F_{\text {fire bc }}=F_{\text {fire }}-F_{\text {nofirebc }}$

$\Delta F_{\text {fire pom }}=F_{\text {fire }}-F_{\text {nofirepom }}$

The total TOA shortwave flux change can be broken into the REari, REaci and REsac. The aerosol REaci results from both the aerosol effect on clouds (i.e., acting as $\mathrm{CCN}$ ) and the aerosol semi-direct effect on clouds (i.e., affecting the atmospheric states due to absorbing aerosols). We adopt the method by Ghan (2013) to separate the REari, REaci and REsac from the total effects of all fire aerosols, fire $\mathrm{BC}$ and fire POM, respectively. The method is summarized as follows. $F_{\text {clean }}$ is the radiative flux at TOA calculated from a diagnostic radiation call in the same control simulations, but neglecting the scattering and absorption of solar radiation by aerosols. $F_{\text {clean,clear }}$ is the clear-sky radiative flux at TOA calculated from the same diagnostic radiation call, but neglecting scattering and absorption by both clouds and aerosols.

$$
\begin{gathered}
\Delta F=\underset{(\text { REari })}{\Delta\left(F-F_{\text {clean }}\right)}+\Delta\left(\begin{array}{c}
\left(F_{\text {clean }}-F_{\text {clean }, \text { clear }}\right) \\
(\text { REaci })
\end{array}\right. \\
+\underset{(\text { REsac })}{\Delta F_{\text {clean }, \text { lear }}}
\end{gathered}
$$

In the method above, REaci includes both aerosol indirect and semi-direct effects. The fire BC has a much weaker indirect effect due to its lower mass burden and lower hygroscopicity compared to fire POM (Koch et al., 2011). Thus, the fire aerosol semi-direct effect can be approximately represented by the REaci of fire BC. The fire aerosol indirect effect can be estimated as the difference between the fire aerosol REaci and semi-direct effect. With the sea ice prescribed in these experiments, the radiative effect of fire aerosols on sea ice albedo is not considered in REsac.

We undertake another method to estimate the fire aerosol REari from the experiment (FIRE_BBFFBF). With explicit predictions of fire POM and fire BC in FIRE_BBFFBF, the
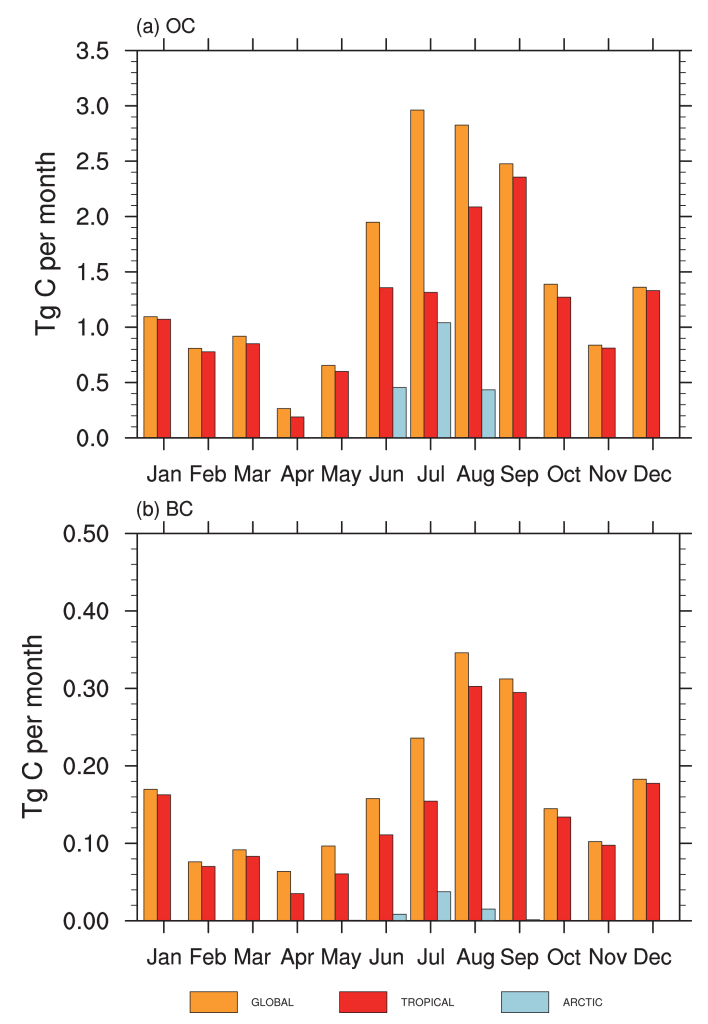

Figure 1. Seasonal variation of GFED monthly fire (a) organic carbon (OC) and (b) black carbon (BC) emissions ( $\mathrm{Tg} \mathrm{C}$ month $^{-1}$ ) averaged for the period of year 2003 to 2011 in the global, tropical $\left(25^{\circ} \mathrm{S}\right.$ to $\left.25^{\circ} \mathrm{N}\right)$ and the Arctic $\left(60\right.$ to $\left.90^{\circ} \mathrm{N}\right)$ regions.

REari of fire BC and fire POM are estimated by two diagnostic radiation calls, each time neglecting the scattering and absorption of solar radiation of fire BC and fire POM. This more direct method is named BBFFBF, and the REari of fire $\mathrm{BC}$ and fire $\mathrm{POM}$ will be compared with those from the method by Ghan (2013). The fire BC-in-snow effect is calculated from SNICAR, and compared with the REsac estimated from Ghan (2013).

\section{Results}

\subsection{Simulation of biomass burning aerosols}

The biomass burning BC and POM from forest, grass and agriculture fires are significant contributors to the total $\mathrm{BC}$ and POM emissions. Figure 1 shows the seasonal variation of GFED fire emissions (including forest, grass and agriculture fires) in the global, tropical $\left(25^{\circ} \mathrm{S}\right.$ to $\left.25^{\circ} \mathrm{N}\right)$, and the Arctic $\left(60\right.$ to $\left.90^{\circ} \mathrm{N}\right)$ regions. Global fire emission is the largest during the boreal summer as well as in the boreal autumn (September/October) when it is the fire season in the tropical regions of the Southern Hemisphere (SH). The tropical fire emission contributes the most to the annual global fire emission ( $80 \%$ for BC and $85 \%$ for OC), compared to other 

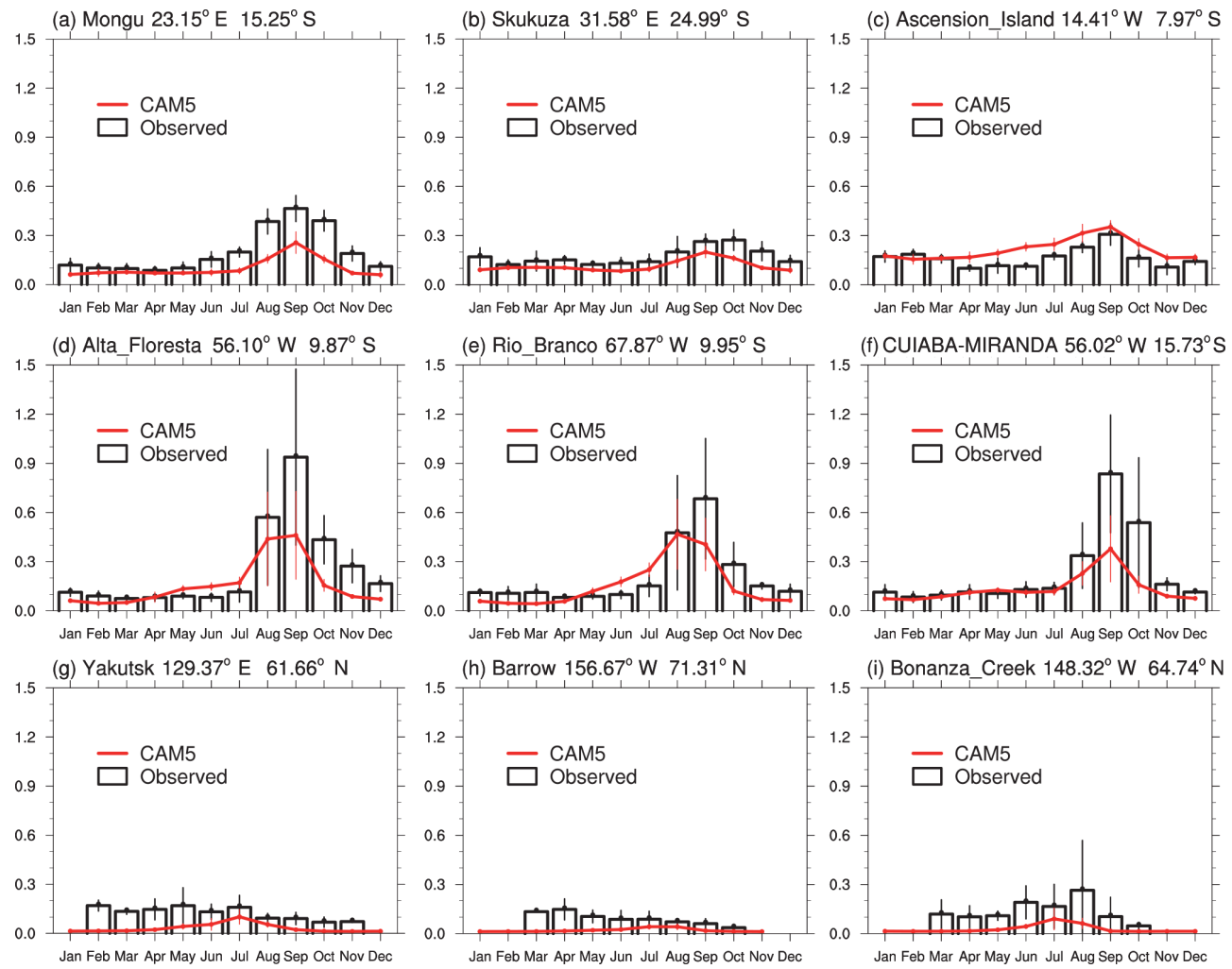

Figure 2. Comparison of modeled seasonal variations of aerosol optical depth (AOD) for the period of 2003-2011 with observations for the same period from the AERONET sites. The upper, middle and bottom panels represent the sites in southern Africa, South America and the Arctic. The vertical bars are $\pm 1 \sigma$ variabilities for the modeled and observed AOD.

regions. The Arctic is the other important fire region, where the emission maximum is found during the boreal summer. In the boreal summer, the $\mathrm{OC}$ emission in the Arctic regions is about $50 \%$ of that in the tropical region. The $\mathrm{BC}$ emission in the Arctic is much smaller than in the tropical regions even in the boreal summer fire season. The dominant fire type in the SH tropics is deforestation, savanna and grassland fires, while that in the Arctic is the forest fires. The $\mathrm{OC}$ to $\mathrm{BC}$ ratio $(\mathrm{OC} / \mathrm{BC})$ of forest fires is almost 3 times higher than that of deforestation, savanna and grassland fires (van der Werf et al., 2010). This is because for forest fires, most of the emissions come from the smoldering phase of burning, which has a higher $\mathrm{OC}$ to $\mathrm{BC}$ ratio. For deforestation, savanna and grassland fires, the emissions come mainly from the flaming phase of burning, which yields a lower OC to BC ratio.

Figure S1 in the Supplement shows the latitudinal and longitudinal distributions of vertically integrated concentrations (column burdens) of BC and POM from BB, FF and BF sources based on the FIRE_BBFFBF experiment. The $\mathrm{BC}$ and POM from the BB source are mainly distributed in the tropical and subtropical regions (southern Africa, South America and Southeast Asia) and in the middle to high latitudes (North of $45^{\circ} \mathrm{N}$ ) of the Northern Hemisphere (NH) (northeast Asia, Alaska and Canada). The largest column burdens of biomass burning aerosols are located in southern Africa and the adjacent oceanic areas $\left(1.5\right.$ and $20 \mathrm{mg} \mathrm{m}^{-2}$ for $\mathrm{BC}$ and POM, respectively). The biomass burning aerosols are important aerosol species in the Arctic regions and contribute up to 53 and $86 \%$ of the total burdens of BC and POM respectively in the Arctic (from 60 to $90^{\circ} \mathrm{N}$ ). In comparison, the maximum column burdens of fossil fuel BC and POM are found in East Asia, southern Asia, western Europe and North America. The maximum column burdens of biofuel BC and POM occur in East Asia, southern Asia and central Africa. The biofuel and fossil fuel sources are dominant contributors to BC and POM in East Asia and southern Asia. In other regions of the world, biomass burning is the primary source of BC and POM. Globally, biomass burning contributes 41 and $70 \%$ to the total burdens of BC and POM, respectively. Biomass burning can also emit $\mathrm{SO}_{2}$. However, it only contributes $\sim 3 \%$ to the total global sulfate burden (figure not shown), so only radiative effects of biomass burning POM and $\mathrm{BC}$ are discussed in this study.

The simulated aerosol optical depth (AOD) and singlescattering albedo (SSA) (including aerosols from all sources) are validated with observations from the AErosol RObotic NETwork (AERONET, http://aeronet.gsfc.nasa.gov) at sites significantly affected by biomass burning activity in southern Africa, South America and the Arctic regions, as shown in 

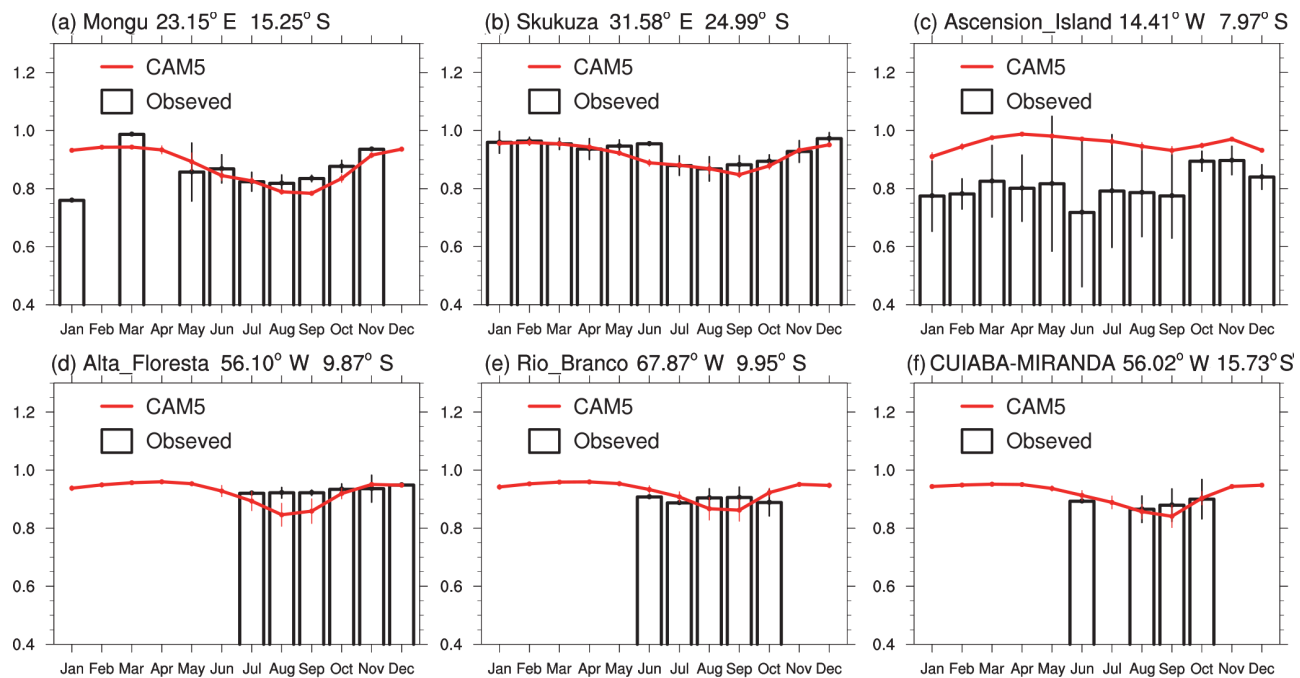

(e) Rio_Branco $67.87^{\circ} \mathrm{W} 9.95^{\circ} \mathrm{S}$
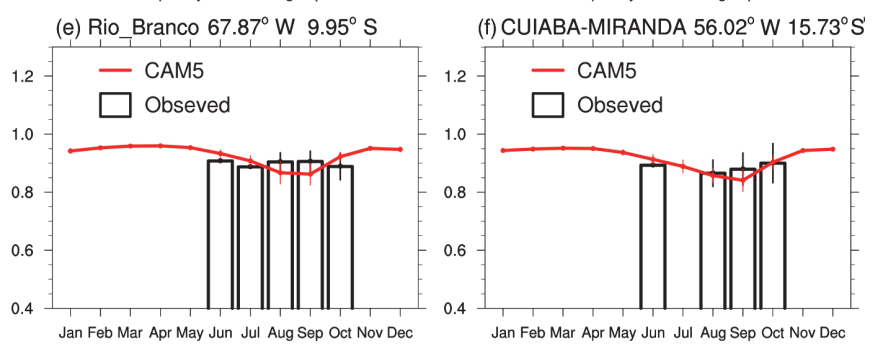

(g) Yakutsk $129.37^{\circ} \mathrm{E} 61.66^{\circ} \mathrm{N}$

(h) Barrow $156.67^{\circ} \mathrm{W} 71.31^{\circ} \mathrm{N}$

(i) Bonanza_Creek $148.32^{\circ} \mathrm{W} 64.74^{\circ} \mathrm{N}$
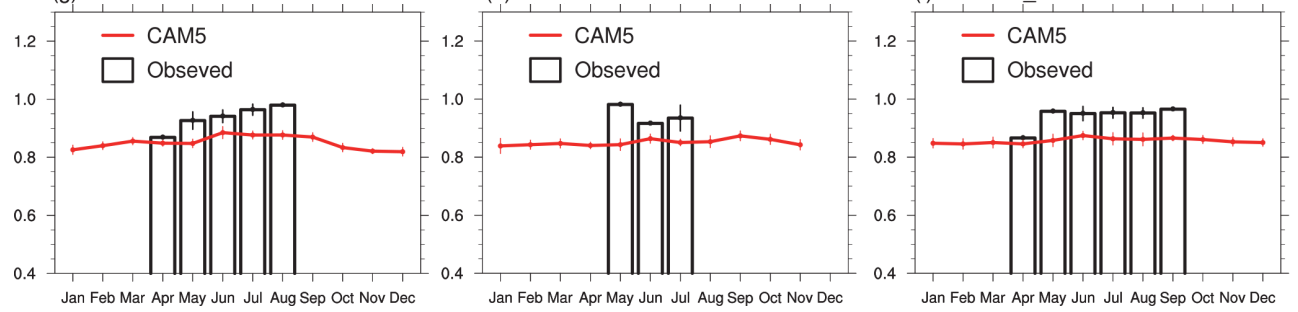

Figure 3. Same as Fig. 2, but for the comparison of single-scattering albedo (SSA) at $550 \mathrm{~nm}$.

Figs. 2 and 3 (see Fig. S2 in the Supplement for the site locations). The AERONET AOD and SSA data are averaged for the years from 2003 to 2011 to match the simulation period, although there are missing AERONET data for some periods. We note that Tosca et al. (2013) and Ward et al. (2012) applied scaling factors (from 1 to 3 varying by regions) to fire emissions to improve modeled AOD magnitudes, whereas here we do not apply any such scaling. In southern Africa, modeled monthly AOD agrees with observations within a factor of 2 for the three sites (Fig. 2a-c). The underestimation of AOD is found in the tropical site (Mongu) (Fig. 2a) during the boreal autumn (the fire season). The simulated AOD in the two other sites (Skukuza and Ascension Island) is generally consistent with observations in both the magnitude and seasonal trend. The simulated SSA in southern Africa ranges between 0.75 and 0.95 and generally matches the observed SSA magnitude and seasonal cycle in the two land sites (Mongu and Skukuza) (Fig. 3a-b). However, an overestimation of SSA is found in the oceanic site (Ascension Island) (Fig. 3c). The reason for this overestimation of SSA and thus the underestimation of absorption AOD (AAOD) is unclear and could be due to the model not treating the absorption enhancement of aged fire BC during its transport.

The simulated AOD in South America is generally consistent with observations within a factor of 2 (Fig. 2d-f). The seasonal variation of simulated AOD generally matches the observations. The underestimation of AOD in Alta Floresta and Cuiaba-Miranda is most obvious in September and October (the fire season), which may be attributed to the underestimation of fire emissions. However, the modeled AOD is higher than the observations before the fire season for Alta Floresta and Rio Branco, which could be due to the overestimation of fire emission in this period. The simulated SSA in South America ranges mostly between 0.87 and 0.95 and matches the observations reasonably well (Fig. 3d-f). The modeled SSA is too low during the fire season and exhibits too strong a seasonality. It implies that the model underestimation of scattering aerosols (e.g., POM) may be more severe than of $\mathrm{BC}$ during the fire season.

In the Arctic, small AOD (less than 0.3) and large SSA (larger than 0.9) are observed for the three sites. The observed large SSA in the fire season (boreal summer) is consistent with the high $\mathrm{OC} / \mathrm{BC}$ ratio of fire emissions in the Arctic (Fig. 1). The model significantly underestimates the observed AOD in the Arctic in both fire and nonfire seasons. The underestimation of AOD can be due to (1) the underestimation of fire emissions in the NH high latitudes (e.g., Stohl et al., 2013) and/or fossil fuel emissions in Asia (e.g., Cohen and Wang, 2014), (2) the excessive scavenging of aerosols during their transport from the $\mathrm{NH}$ midlatitude industrial regions by liquid-phase clouds (Wang et al., 2013a) and (3) the coarse horizontal resolution $(\sim 100 \mathrm{~km})$ of the model (Ma et al., 2014). Although MAM4 increases the column burdens of POM and BC by up to $40 \%$ in many remote regions com- 


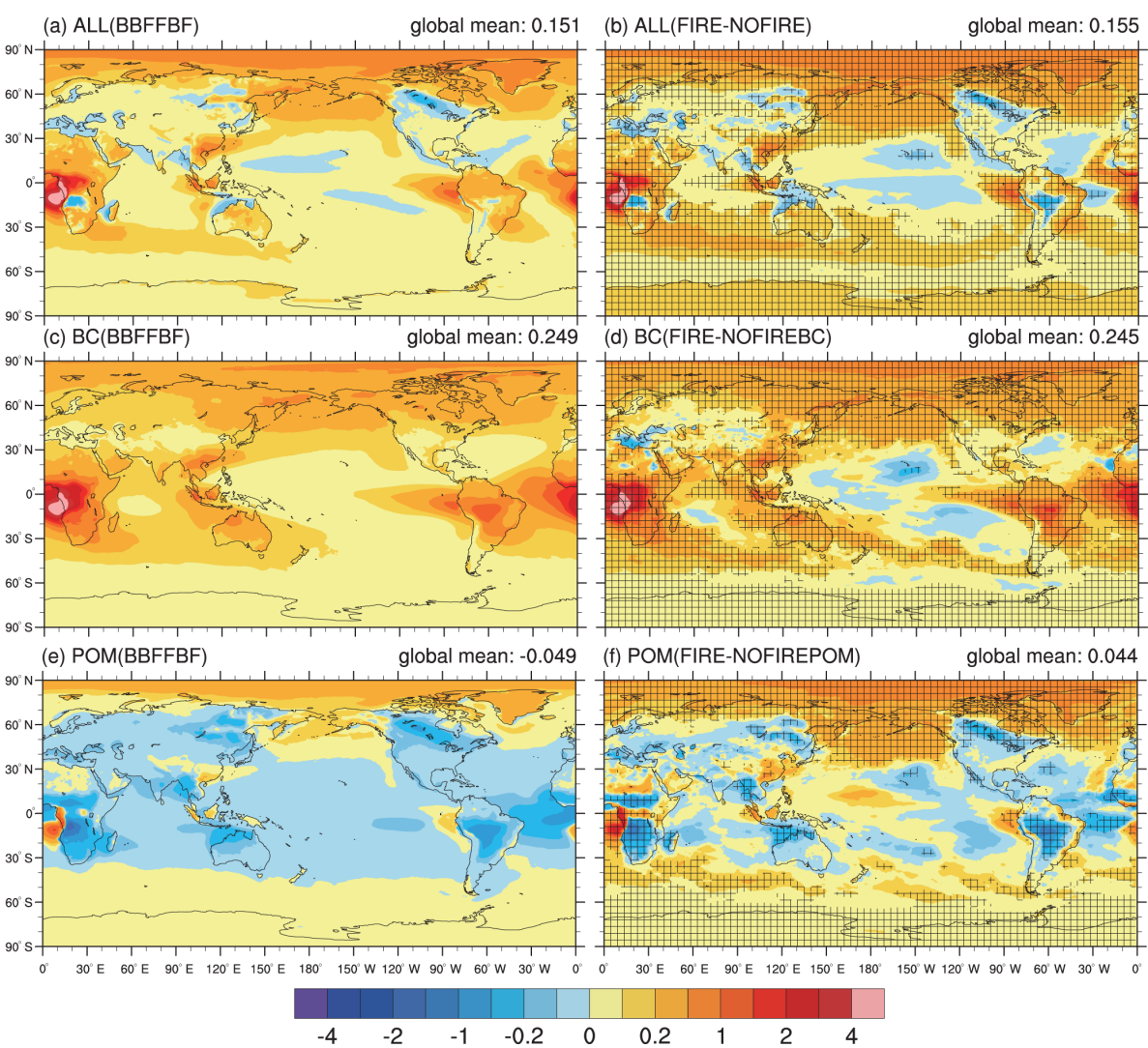

Figure 4. Annual mean radiative effect due to aerosol-radiation interactions (REari) $\left(\mathrm{W} \mathrm{m}^{-2}\right)$ averaged over the period of $2003-2011$ due to (a) all fire aerosols, (c) fire BC and (e) fire POM estimated with the method of BBFFBF (left panels) and with the method by Ghan (2013) (b, $\mathbf{d}, \mathbf{f}$ in the right panels). The plus signs in (b, d, f) denote the regions where the radiative effect estimated with Ghan (2013) is statistically significant at the 0.05 level.

pared to MAM3, it still underestimates the surface BC concentrations in the Arctic (Liu et al., 2016). The modeled SSA in the Arctic is lower than the observations, which implies that the simulation of AAOD is better than of AOD and the underestimation of nonabsorbing aerosols (e.g., sulfate and $\mathrm{POM}$ ) in the Arctic may be more severe than of BC.

\subsection{Radiative effect due to aerosol-radiation interactions}

The annual mean REari of all fire aerosols (including BC, POM and sulfate) estimated with the method of BBFFBF and with the method by Ghan (2013) is shown in Fig. 4a-b. The fire sulfate is not included in the calculation of REari of all fire aerosols with the method of BBFFBF. Its effect is minor since the global annual mean burden of fire sulfate $\left(0.09 \mathrm{mg} \mathrm{m}^{-2}\right)$ is much smaller than of fire POM $\left(1.25 \mathrm{mg} \mathrm{m}^{-2}\right)$, but both are light scattering. The statistical significance of REari estimated with the Ghan (2013) method over the interannual variability and ensemble member diversity is shown in Fig. 4 (and also later figures). The REari of all fire aerosols from the two methods agree with each other very well. Thus, we will report the REari of all fire aerosols using the Ghan (2013) method below. The global annual mean REari of all fire aerosols is positive $\left(0.16 \pm 0.01 \mathrm{~W} \mathrm{~m}^{-2}\right)$, which indicates a warming effect from all fire aerosols. The REari is positive on the globe except in some land areas (e.g., southern Africa, South America, the Great Lakes, northern Canada and Eastern Siberia). The maximum positive REari is located in ocean areas west of southern Africa $\left(\sim 5.0 \mathrm{~W} \mathrm{~m}^{-2}\right)$ and South America $\left(\sim 1.5 \mathrm{~W} \mathrm{~m}^{-2}\right)$. Positive REari up to $1 \mathrm{~W} \mathrm{~m}^{-2}$ is found in the Arctic $\left(60\right.$ to $\left.90^{\circ} \mathrm{N}\right)$. The different signs of REari between land and ocean areas of southern Africa and South America result from the differences in cloud fraction and cloud liquid water path (LWP) between land and ocean regions. In the fire season (August-September-October) of the SH tropical regions, cloud fraction and cloud LWP over the land areas ( $10 \%$ and $20 \mathrm{~g} \mathrm{~m}^{-2}$, respectively) are much smaller than those over the adjacent ocean areas $\left(70 \%\right.$ and $\left.70 \mathrm{~g} \mathrm{~m}^{-2}\right)$. The biomass burning aerosols are transported above the low-level stratocumulus clouds, and when biomass burning $\mathrm{BC}$ resides above clouds, its absorption of solar radiation is significantly enhanced due to the reflection of solar radiation by underlying clouds (Abel et al., 2005; Zhang et al., 2016). 
(a) CAM5
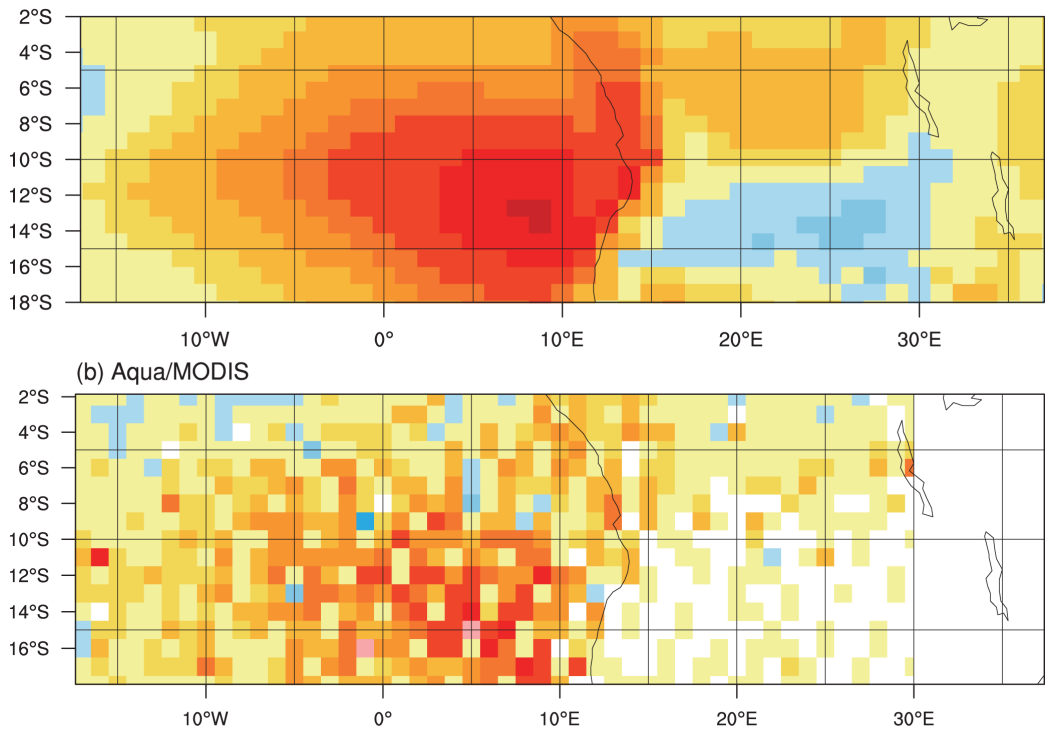

(c) Terra/MODIS

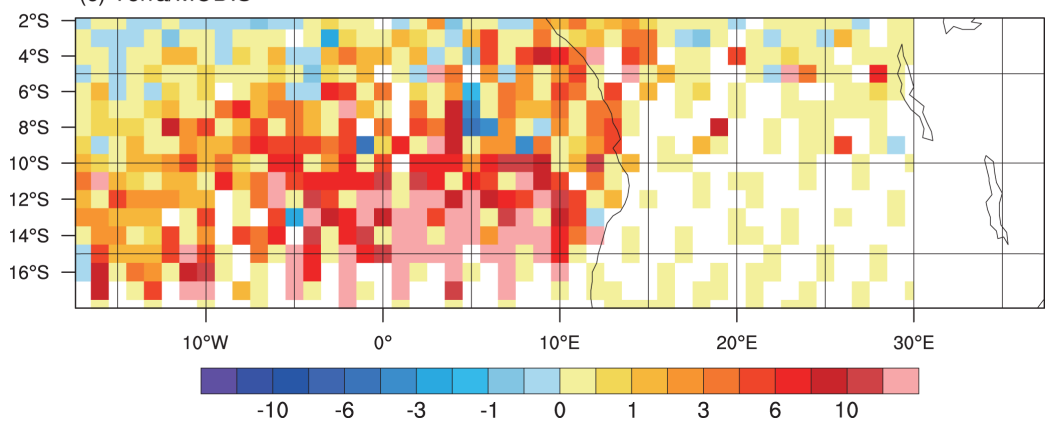

Figure 5. (a) September-October-November (SON) mean fire aerosol radiative effects due to aerosol-radiation interactions (REari) $\left(\mathrm{W} \mathrm{m}^{-2}\right.$ ) for the period of 2003-2011 over the southeast Atlantic Ocean due to all fire aerosols. Panels (b, c) are the same as (a), but for the above-cloud aerosol REari for the period of 2007-2011 estimated using Aqua/MODIS and Terra/MODIS products (Zhang et al., 2014).

A comparison of modeled REari in the boreal autumn (September-October-November) over the South Atlantic Ocean with satellite observations is shown in Fig. 5. The observed above-cloud aerosol REari is calculated with the method by Zhang et al. (2014) using the Aqua/MODIS and Terra/MODIS products. The observed above-cloud aerosol REari over southeastern Atlantic Ocean is $3-12 \mathrm{~W} \mathrm{~m}^{-2}$, with higher values near the coasts. The simulated REari agrees better with Aqua/MODIS-observed REari than with Terra/MODIS in both the magnitude and spatial pattern. REari estimated from Terra/MODIS (morning time) is stronger than REari estimated from Aqua/MODIS (afternoon time) due to the larger amount of underlying cloud in the morning (Min and Zhang, 2014). Over South America during the fire season (August to September), the clearsky fire aerosol REari is estimated to be $-5.2 \mathrm{~W} \mathrm{~m}^{-2}$ by Sena and Artaxo (2015), which is larger than our model result $\left(-2.1 \mathrm{~W} \mathrm{~m}^{-2}\right)$. This is consistent with the underestimation of modeled AOD in South America compared to the AERONET data (Fig. 2).
The seasonal variation of REari of all fire aerosols with the Ghan (2013) method is shown in Fig. S3 in the Supplement. The REari has a maximum $\left(1.13 \mathrm{~W} \mathrm{~m}^{-2}\right)$ in the boreal summer (June-July-August, JJA) over the Arctic regions, partially due to the low solar zenith angles there. The maximum positive REari in the tropical regions occurs in the boreal summer and autumn (September, October and November, SON) during the fire season of southern Africa and South America. The REari reaches a positive maximum in Southeast Asia during the fire season in March, April and May (MAM).

The REari of fire BC is shown in Fig. 4c-d. The fire BC REari calculated from the two methods are similar in magnitudes and spatial patterns, and there is much less noise with the BBFFBF method. The global annual mean fire BC REari is about $0.25 \pm 0.01 \mathrm{~W} \mathrm{~m}^{-2}$ and positive over the globe (the regions with negative values in Fig. $4 \mathrm{~d}$ are in general not statistically significant). Unlike all fire aerosols, fire BC generates a positive forcing in the land regions of southern Africa and South America, and the amplification effect of low-level 
(a) ALL

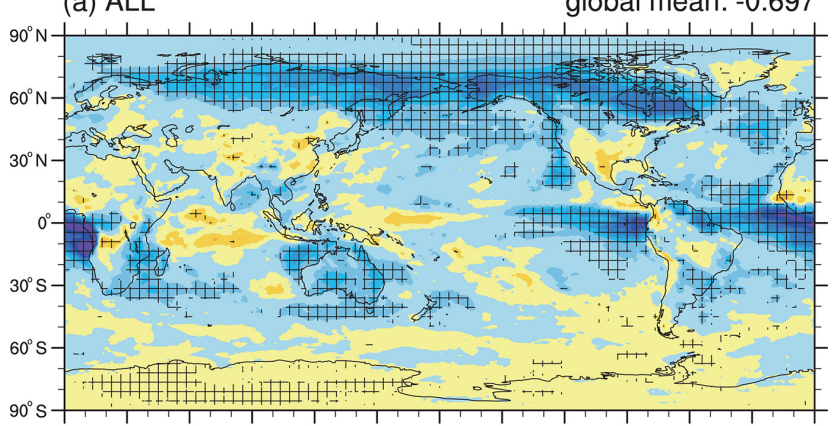

(b) $\mathrm{BC}$

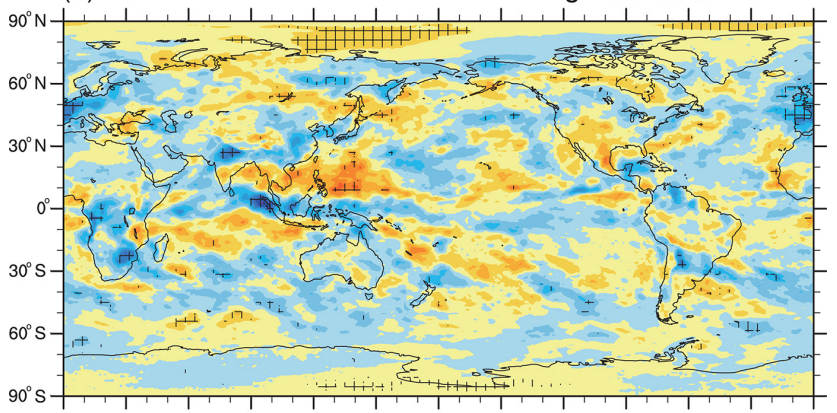

(c) POM

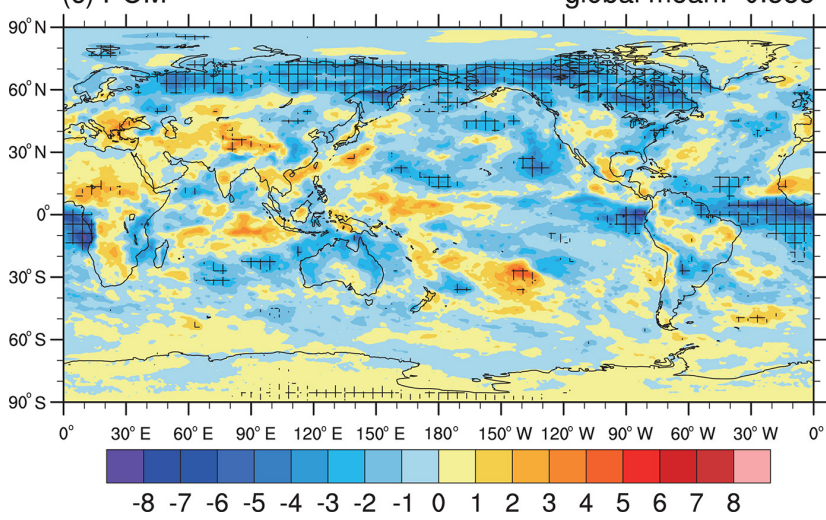

Figure 6. Annual mean radiative effects due to aerosol-cloud interactions (REaci) $\left(\mathrm{W} \mathrm{m}^{-2}\right)$ averaged over the period of 2003-2011 due to (a) all fire aerosols, (b) fire BC and (c) fire POM. The plus signs denote the regions where the radiative effect is statistically significant at the 0.1 level.

clouds on fire $\mathrm{BC}$ positive forcing can be clearly seen in southern Africa and the adjacent Atlantic Ocean.

The global annual mean REari values of fire POM from the two methods somewhat differ from each other (Fig. 4ef). The BBFFBF method gives a small negative value $\left(-0.05 \mathrm{~W} \mathrm{~m}^{-2}\right)$, while the Ghan (2013) method shows a small positive value $\left(0.04 \pm 0.01 \mathrm{~W} \mathrm{~m}^{-2}\right)$. The difference is mainly in the Arctic regions where the positive forcing from Ghan (2013) is larger than from the BBFFBF method. This is because the removal of fire POM emissions in the NOFIREPOM experiment affects the properties of aerosol particles within which co-emitted fire $\mathrm{BC}$ is internally mixed with fire POM, causing a decrease of $\mathrm{BC}$ burden in the Arc- tic (by $\sim 0.05 \mathrm{mg} \mathrm{m}^{-2}$ ) compared to the FIRE experiment. Thus, one should be careful when using the Ghan (2013) method to diagnose the radiative forcing of a single component within co-emitted aerosols. The REari of fire POM is negative across most of the globe. However, positive forcing can be found over oceanic regions west of southern Africa and South America, the North Pacific Ocean and the Polar regions, where large amounts of low-level cloud, sea ice or land ice exist. The multiple scatterings between the above-cloud fire POM and low-level clouds or between the fire POM and the Earth's bright surface with high albedos could reduce the amount of solar radiation reflected by these low-level clouds and bright surfaces in the case without the fire POM (Zhang et al., 2016). With the BBFFBF method, the sum of REari from fire POM and fire $\mathrm{BC}$ (i.e., $0.20 \mathrm{~W} \mathrm{~m}^{-2}$ ) is larger than that of all fire aerosols $\left(0.15 \mathrm{~W} \mathrm{~m}^{-2}\right)$. It reflects the nonlinear interactions among different aerosol components (Ghan et al., 2012). For example, fire POM and water on internally mixed fire BC particles enhance solar absorption by fire BC. The nonlinearity is stronger with the Ghan (2013) method.

\subsection{Radiative effect due to aerosol-cloud interactions}

The annual mean REaci due to all fire aerosols, fire BC and fire POM are shown in Fig. 6. The REaci diagnosed with the Ghan (2013) method includes both aerosol indirect and semidirect effects. The fire aerosol semi-direct effect (to be discussed below) is much smaller $\left(-0.04 \pm 0.03 \mathrm{~W} \mathrm{~m}^{-2}\right.$ on the global mean) than the indirect effect, and the REaci is mostly from the fire aerosol indirect effect. The global annual mean REaci of all fire aerosols is $-0.70 \pm 0.05 \mathrm{~W} \mathrm{~m}^{-2}$ (Fig. 6a). In the tropical regions, the strong negative REaci is located in the adjacent ocean areas of southern Africa, South America and Australia, with the maximum REaci of $-8.0 \mathrm{~W} \mathrm{~m}^{-2}$ over the South Atlantic Ocean. The strong negative REaci also occurs in the Arctic $\left(60\right.$ to $\left.90^{\circ} \mathrm{N}\right)$. The REaci in Eastern Siberia, Alaska and Canada is as large as $-6.0 \mathrm{~W} \mathrm{~m}^{-2}$.

The fire $\mathrm{BC}$ has a weak indirect effect by acting as $\mathrm{CCN}$, but can reduce the amount of cloud through its semi-direct effect. The REaci of fire BC (Fig. 6b) can approximate the fire $\mathrm{BC}$ semi-direct effect with a small global annual mean value of $-0.04 \pm 0.03 \mathrm{~W} \mathrm{~m}^{-2}$. However, a stronger positive effect can be found in the western Pacific $\left(3.0 \mathrm{~W} \mathrm{~m}^{-2}\right)$ and Arctic regions $\left(1.0 \mathrm{~W} \mathrm{~m}^{-2}\right)$. The global annual mean REaci of fire POM is $-0.59 \pm 0.03 \mathrm{~W} \mathrm{~m}^{-2}$ (Fig. 6c) and dominates the cloud effect of all fire aerosols. The sum of REaci from fire BC and POM $\left(-0.62 \pm 0.03 \mathrm{~W} \mathrm{~m}^{-2}\right)$ is smaller in magnitude than from all fire aerosols $\left(-0.70 \pm 0.05 \mathrm{~W} \mathrm{~m}^{-2}\right)$ due to the nonlinear interactions of fire BC and fire POM (Jiang et al., 2013) as well as the negative REaci of fire sulfate. As an example of the nonlinear interactions, the internal mixing of fire POM and fire BC by all fire aerosols enhances the cloud droplet number concentration in comparison to the sum of cloud droplet number concentrations from individual fire POM and fire BC (Jiang et al., 2013). 


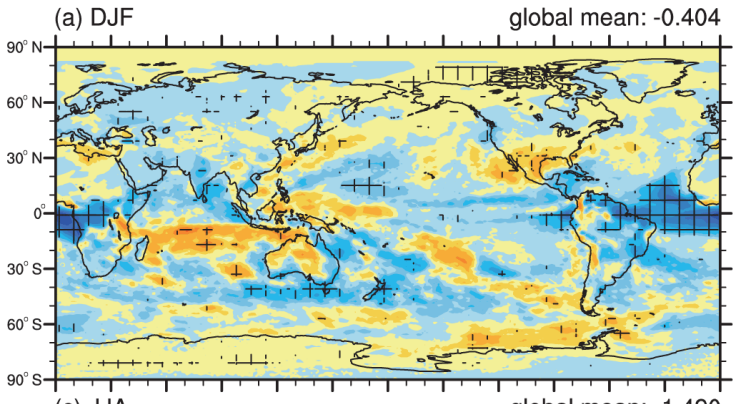

(c) JJA

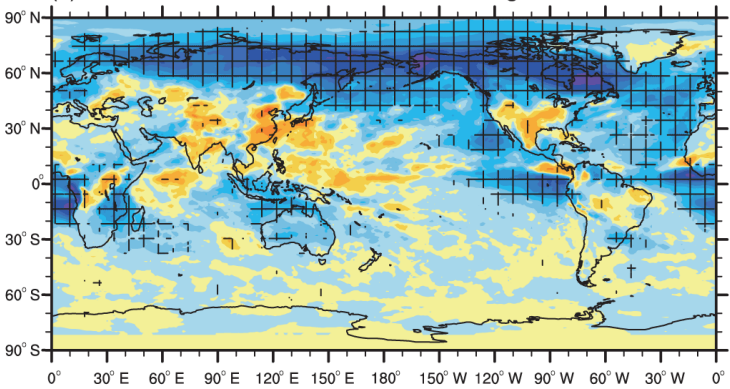

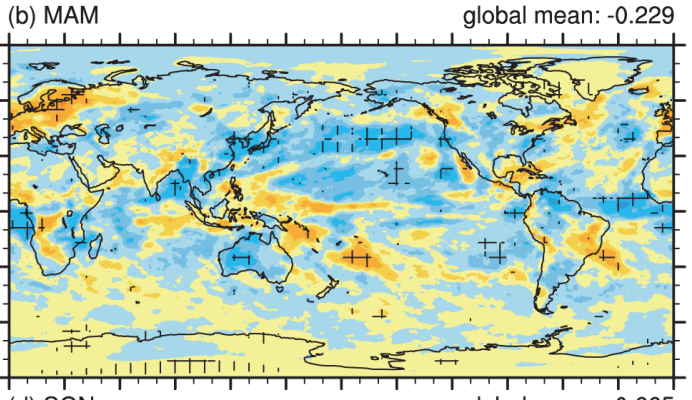
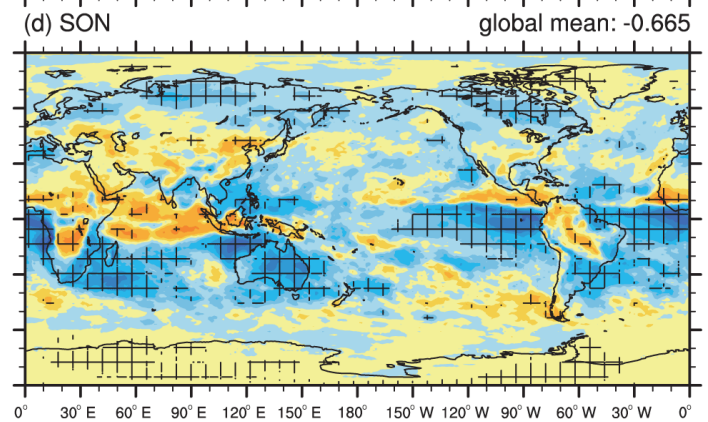

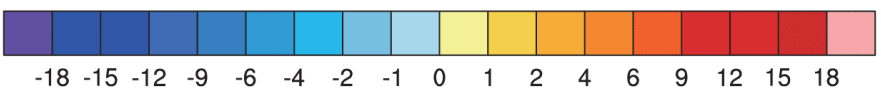

Figure 7. Seasonal variation of radiative effects of all fire aerosols due to aerosol-cloud interactions (REaci) (W m ${ }^{-2}$ ) for the period of 2003-2011 for (a) December-January-February (DJF), (b) March-April-May (MAM), (c) June-July-August (JJA) and (d) SeptemberOctober-November (SON). The plus signs denote the regions where the radiative effect is statistically significant at the 0.05 level.

The seasonal variation of all fire aerosol REaci is shown in Fig. 7. The maximum of fire aerosol REaci is in the boreal summer (i.e., the fire season in $\mathrm{NH}$ ), located in the $\mathrm{NH}$ high latitudes $\left(60\right.$ to $\left.90^{\circ} \mathrm{N}\right)$. The largest summer REaci is found in the land areas and is as large as $-15 \mathrm{~W} \mathrm{~m}^{-2}$. The fire aerosol REaci in the tropical regions is most significant in the boreal summer (up to $-15 \mathrm{~W} \mathrm{~m}^{-2}$ ) and autumn (up to $-10 \mathrm{~W} \mathrm{~m}^{-2}$ ) over the ocean areas. The different spatial distributions of fire aerosol REaci in the $\mathrm{NH}$ high latitudes and in the tropics result from the difference in cloud distribution between the two regions. During the fire season the cloud LWP over the land areas in the NH middle and high latitudes is 3 times larger than over the ocean areas in the tropics. Larger cloud LWP favors the stronger REaci, because a larger LWP associated with warm cloud and rain processes favors the aerosol indirect effect of slowing down the autoconversion of cloud water to rain (Ghan et al., 2012; Jiang et al., 2015). Meanwhile, in the NH high latitudes, the lower solar zenith angle in the boreal summer favors the stronger REaci. Like the fire aerosol REari, the smallest fire aerosol REaci occurs in the boreal spring.

Seasonal variations of zonal mean fire aerosol REari, REaci, cloud LWP, amount of low-level (from surface to $750 \mathrm{hPa}$ ) cloud and vertically integrated (burden) concentrations of fire POM and fire BC are shown in Fig. 8. The seasonal variation of fire $\mathrm{BC}$ and fire POM burdens is largest in the $\mathrm{SH}$ low latitudes (from $30^{\circ} \mathrm{S}$ to $0^{\circ} \mathrm{N}$ ) and $\mathrm{NH}$ mid- dle and high latitudes (50 to $\left.90^{\circ} \mathrm{N}\right)$. A distinct feature of these two areas is that the maximum fire $\mathrm{BC}$ burden in $\mathrm{NH}$ $\left(0.3 \mathrm{mg} \mathrm{m}^{-2}\right)$ is much lower than in $\mathrm{SH}\left(0.8 \mathrm{mg} \mathrm{m}^{-2}\right)$, while the maximum POM burdens in these two areas are comparable. Interestingly, the REari is larger in the boreal summer in $\mathrm{NH}$ than in the boreal autumn in $\mathrm{SH}$, although the fire $\mathrm{BC}$ burden is much lower in the $\mathrm{NH}$ summer. It is mainly due to the larger amount of low cloud in the NH high latitudes, which enhances the absorption of fire BC. The maximum REari in the NH summer is found near the North Pole (70 to $90^{\circ} \mathrm{N}$ ) and not around $60^{\circ} \mathrm{N}$ where the fire aerosol burden is highest. The REaci of fire aerosols is about 3 times larger in the boreal summer in $\mathrm{NH}$ than in the boreal autumn in $\mathrm{SH}$, although the burden of fire POM in NH is comparable to that in SH. The larger cloud LWP in the NH summer around $40-70^{\circ} \mathrm{N}$ favors the stronger REaci there.

\subsection{Surface-albedo effect}

Here we compare the modeled BC-in-snow (BCS) concentrations with observation data collected from multiple field campaigns over the Arctic (Doherty et al., 2010) and northern China (Wang et al., 2013b; Qian et al., 2014). Figure 9a shows the simulated (from FIRE and NOFIRE experiments) and observed BCS concentrations as a function of latitude. The range of observed BCS concentrations is between 1 and $200 \mathrm{ng} \mathrm{g}^{-1}$ in the Arctic and between 50 and $2000 \mathrm{ng} \mathrm{g}^{-1}$ in 

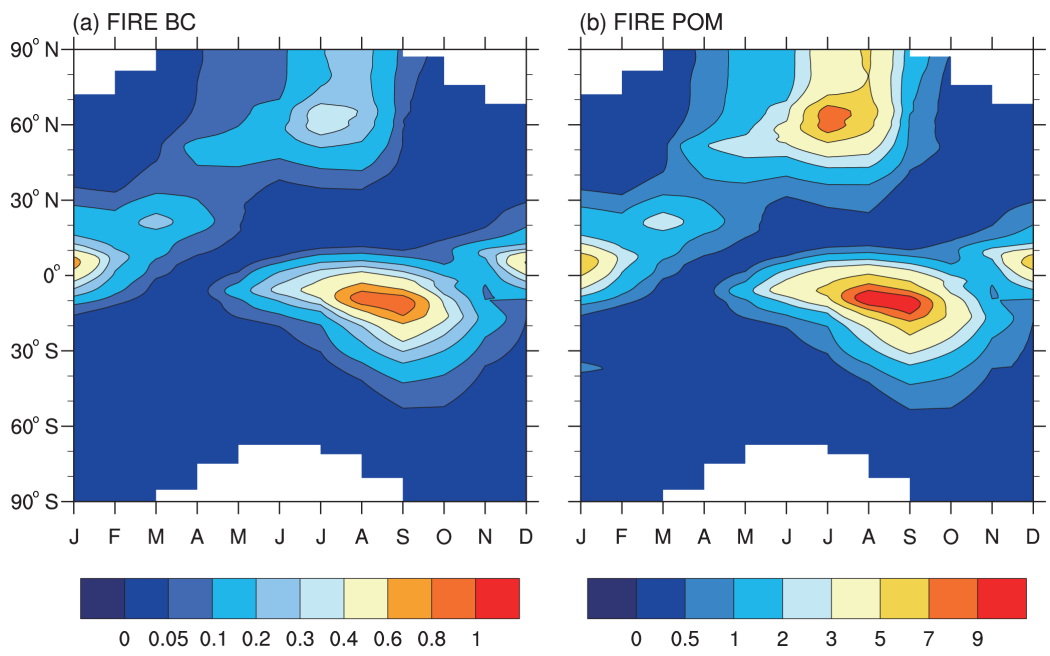

(c) LWP
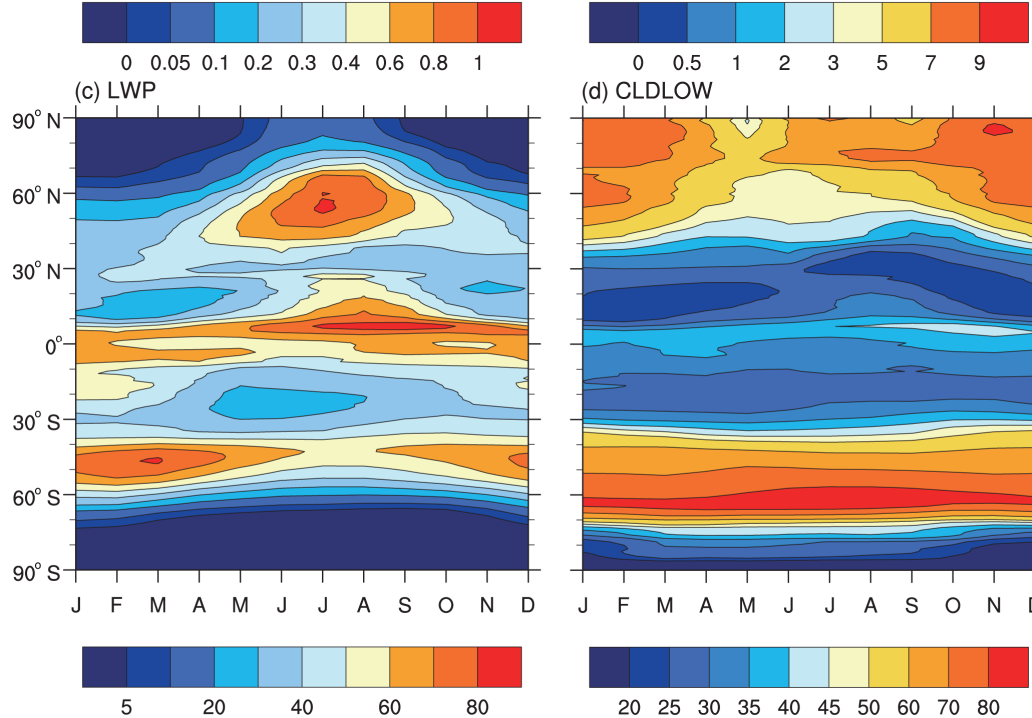

(d) CLDLOW

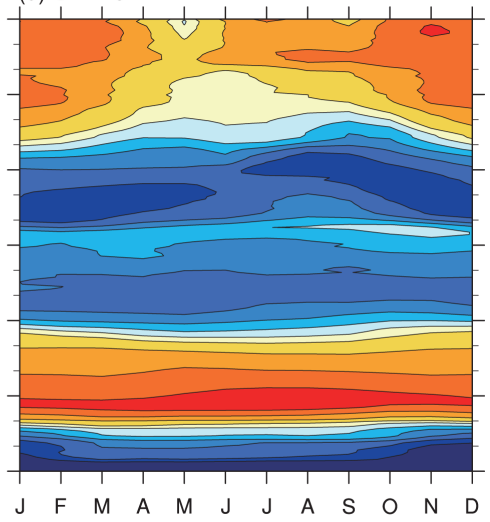

$\begin{array}{llllllllll}20 & 25 & 30 & 35 & 40 & 45 & 50 & 60 & 70 & 80\end{array}$
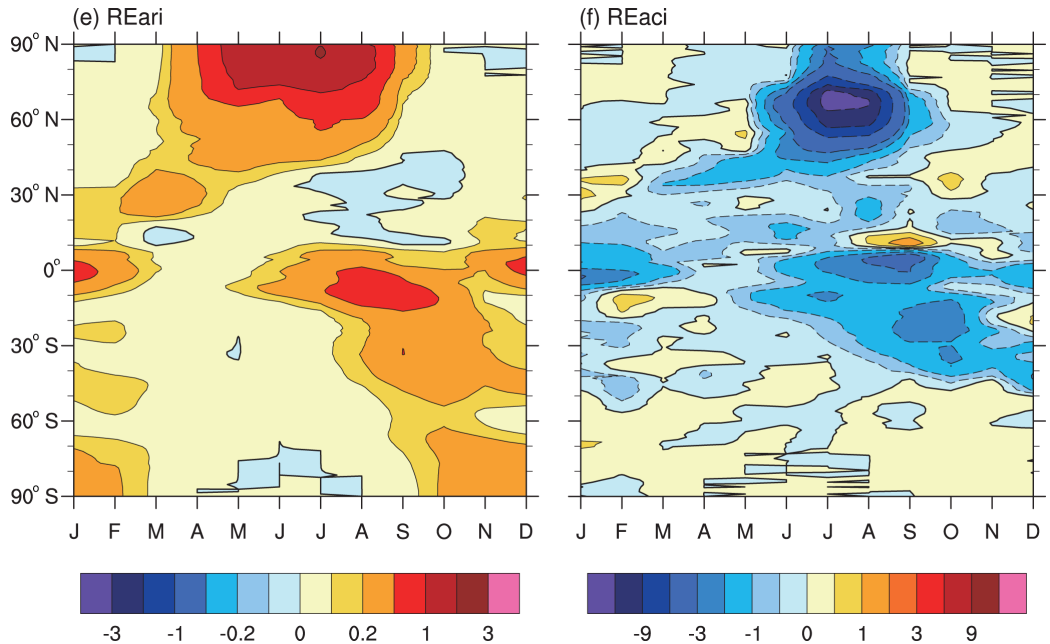

Figure 8. Time-latitude cross sections of zonal mean and monthly (a) vertically integrated concentrations $\left(\mathrm{mg} \mathrm{m}^{-2}\right)$ of fire $\mathrm{BC}$ and (b) fire POM, (c) cloud liquid water path (LWP, in $\mathrm{g} \mathrm{m}^{-2}$ ), (d) low-level cloud cover (CLDLOW, in \%), (e) radiative effect due to aerosol-radiation interactions (REari, in $\mathrm{W} \mathrm{m}^{-2}$ ) and (f) radiative effect due to aerosol-cloud interactions (REaci, in $\mathrm{W} \mathrm{m}^{-2}$ ) of all fire aerosols. 

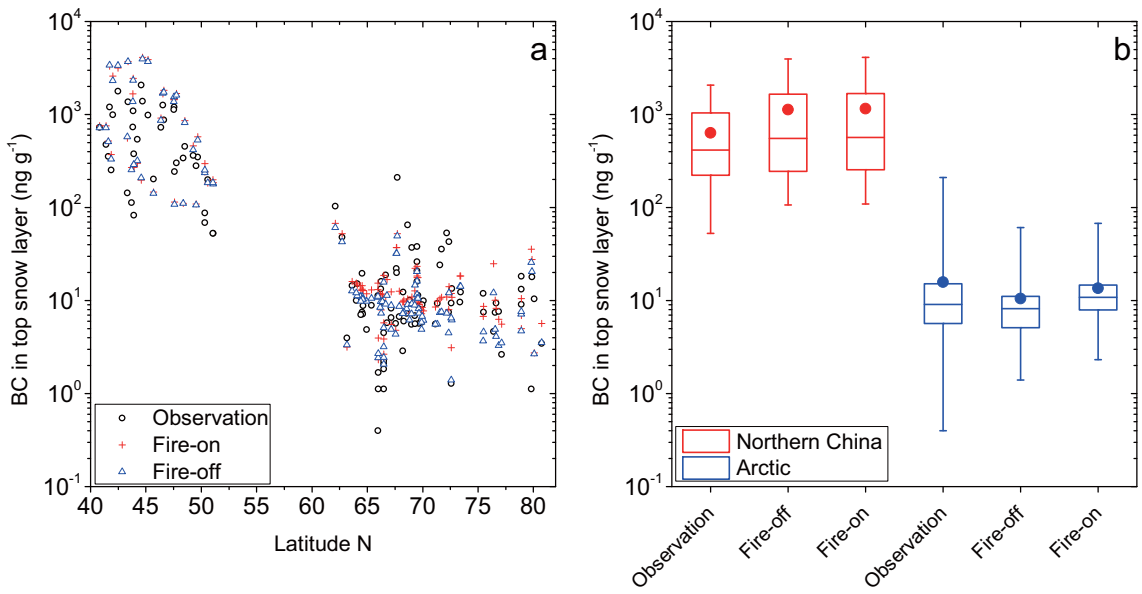

Figure 9. Evaluation of CAM5-simulated black carbon (BC) concentration for the period of 2003-2011 (in $\mathrm{ng} \mathrm{g}^{-1}$ ) in the top snow layer against observations in the Arctic (Doherty et al., 2010) and northern China (Wang et al., 2013b). The top snow layer ranges in thickness from 1 to $3 \mathrm{~cm}$. Configuration of the two CAM5 simulations (FIRE and NOFIRE) is summarized in Table 1. Panel (a) shows the comparisons at different latitudes. The box and whisker plot in (b) shows the minimum and maximum value with the bar, the 25 th and 75 th percentiles with the box, the 50th percentile (i.e., median) by the bar within the box and the mean value with the dot.

northern China. Both FIRE and NOFIRE experiments capture the meridional gradient in BCS concentrations between the midlatitudes (northern China) and high latitudes (Arctic). The mean and median concentrations of BCS are both overestimated in northern China, implying high biases from the anthropogenic emissions and/or model physics (Fig. 9b). The mean and median BCS concentrations from the FIRE experiment agree slightly better with the observations than those from the NOFIRE experiment in the Arctic (Fig. 9b). This suggests that fire emissions are important for BCS concentrations in the Arctic.

The annual mean REsac of all fire aerosols estimated with Ghan (2013) and the fire BCS effect diagnosed from SNICAR are shown in Fig. 10a. We note that the radiative effect due to $\mathrm{BC}$ deposition on sea ice is not considered since sea ice is prescribed in the simulations. The global annual mean REsac $\left(0.03 \pm 0.10 \mathrm{~W} \mathrm{~m}^{-2}\right)$ is much smaller compared to the REari and REaci. The REsac over land is maximum in spring $\left(0.12 \pm 0.27 \mathrm{~W} \mathrm{~m}^{-2}\right)$ and winter $\left(0.06 \pm 0.16 \mathrm{~W} \mathrm{~m}^{-2}\right)$. The REsac over land in summer and autumn is very small (less than $0.01 \mathrm{~W} \mathrm{~m}^{-2}$ ). We note that the mean REsac calculated from Ghan (2013) is much smaller than the standard deviation which resulted from the internal variability.

The annual mean fire BCS effect calculated from SNICAR is shown in Fig. 10b and c. The spatial distribution of the fire BCS effect is similar to the fire REsac, implying that the fire REsac has a significant contribution from the fire BCS effect. Averaged when only snow is present, the fire BCS effect is larger $\left(0.048 \mathrm{~W} \mathrm{~m}^{-2}\right)$. The global mean fire BCS effect (with the presence of snow) can be as large as $0.06 \mathrm{~W} \mathrm{~m}^{-2}$ in spring. The maximum fire BCS effect (up to $1 \mathrm{~W} \mathrm{~m}^{-2}$ ) is located in Greenland and the very northern reaches of Canada, while in the other Arctic regions and northern China it is smaller.

The positive REsac in Siberia, North America and Canada can be a result of the BCS effect. However, the REsac in these regions is larger than the BCS effect especially in spring. The snow melting and snow depth change due to the BCS warming may induce a larger positive REsac than the albedo change due to BCS itself. The negative REsac over land can be a result of atmospheric feedbacks caused by fire aerosols (Ghan, 2013).

\subsection{Fire aerosol effects on shortwave radiation, global temperature and precipitation}

Here, we show the annual mean net shortwave flux changes at TOA (i.e., total radiative effect), in the atmosphere and at the surface as well as changes in surface air temperature, convective and large-scale precipitation due to all fire aerosols in Fig. 11 and Table 2. The global mean net shortwave flux change at TOA due to all fire aerosols is $-0.55 \pm 0.07 \mathrm{~W} \mathrm{~m}^{-2}$, which indicates that fire aerosols lead to the reduction of shortwave flux into the Earth's system. The zonal mean TOA shortwave flux reduction in the Arctic regions $\left(-1.35 \pm 1.03 \mathrm{~W} \mathrm{~m}^{-2}\right)$ is much larger than in the tropical regions $\left(-0.66 \pm 0.09 \mathrm{~W} \mathrm{~m}^{-2}\right)$. The cooling at TOA is mostly from fire aerosol REaci. The maximum negative $\mathrm{RE}$ is located in the land areas of the Arctic and ocean areas of the tropics. Although the global mean total radiative effect is negative, a positive effect is found in some land areas (e.g., Africa, Greenland). 
Table 2. Global, tropics $\left(25^{\circ} \mathrm{S}\right.$ to $\left.25^{\circ} \mathrm{N}\right)$ and Arctic $\left(60\right.$ to $\left.90^{\circ} \mathrm{N}\right)$ annual mean fire aerosol (POM and BC) burdens, fire aerosol AOD, total fire aerosol radiative effect (RE) at TOA, radiative effects due to aerosol-radiation interactions (REari), due to aerosol-cloud interactions (REaci), surface-albedo changes (REsac) and changes in cloud liquid water path (LWP), low-level cloud cover, net solar fluxes at the surface, shortwave atmospheric absorption, surface air temperature and precipitation (total, convective and large scale) due to all fire aerosols. Standard deviations about the 10-ensemble means are included.

\begin{tabular}{|c|c|c|c|}
\hline & Global & $\begin{array}{r}\text { Tropics } \\
\left(25^{\circ} \mathrm{S} \text { to } 25^{\circ} \mathrm{N}\right)\end{array}$ & $\begin{array}{r}\text { Arctic } \\
\left(60 \text { to } 90^{\circ} \mathrm{N}\right)\end{array}$ \\
\hline Fire POM burden $\left(\mathrm{mg} \mathrm{m}^{-2}\right)$ & $1.25 \pm 0.01$ & $1.87 \pm 0.01$ & $1.70 \pm 0.08$ \\
\hline Fire $\mathrm{BC}$ burden $\left(\mathrm{mg} \mathrm{m}^{-2}\right)$ & $0.106 \pm 0.001$ & $0.17 \pm 0.001$ & $0.09 \pm 0.004$ \\
\hline Fire aerosol optical depth & $0.008 \pm 0.001$ & $0.012 \pm 0.001$ & $0.007 \pm 0.0004$ \\
\hline Total radiative effect $\left(\mathrm{W} \mathrm{m}^{-2}\right)$ & $-0.55 \pm 0.07$ & $-0.66 \pm 0.09$ & $-1.35 \pm 1.03$ \\
\hline Radiative effect due to ARI ( $\mathrm{W} \mathrm{m}^{-2}$ ) & $0.16 \pm 0.01$ & $0.17 \pm 0.017$ & $0.43 \pm 0.028$ \\
\hline Radiative effect due to ACI ( $\mathrm{W} \mathrm{m}^{-2}$ ) & $-0.70 \pm 0.05$ & $-0.82 \pm 0.09$ & $-1.38 \pm 0.23$ \\
\hline Radiative effect due to surface-albedo changes (over land, $\mathrm{W} \mathrm{m}^{-2}$ ) & $0.03 \pm 0.10$ & $-0.04 \pm 0.06$ & $0.09 \pm 0.80$ \\
\hline Cloud liquid water path $\left(\mathrm{g} \mathrm{m}^{-2}\right)$ & $1.62 \pm 0.01$ & $1.95 \pm 0.13$ & $2.59 \pm 0.25$ \\
\hline Low-level cloud cover $(\%)$ & $0.012 \pm 0.06$ & $-0.055 \pm 0.05$ & $0.46 \pm 0.45$ \\
\hline Net solar flux at surface $\left(\mathrm{W} \mathrm{m}^{-2}\right)$ & $-1.38 \pm 0.05$ & $-1.91 \pm 0.12$ & $-2.27 \pm 1.04$ \\
\hline Shortwave atmospheric absorption $\left(\mathrm{W} \mathrm{m}^{-2}\right)$ & $0.83 \pm 0.03$ & $1.25 \pm 0.04$ & $0.92 \pm 0.05$ \\
\hline Surface air temperature $(\mathrm{K})$ & $-0.03 \pm 0.03$ & $-0.024 \pm 0.011$ & $-0.15 \pm 0.20$ \\
\hline Total precipitation rate $\left(\mathrm{mm} \mathrm{day}^{-1}\right)$ & $-0.010 \pm 0.002$ & $-0.016 \pm 0.01$ & $-0.001 \pm 0.02$ \\
\hline Convective precipitation rate $\left(\mathrm{mm} \mathrm{day}^{-1}\right)$ & $-0.003 \pm 0.002$ & $-0.001 \pm 0.009$ & $-0.005 \pm 0.003$ \\
\hline Large-scale precipitation rate $\left(\mathrm{mm}\right.$ day $\left.^{-1}\right)$ & $-0.007 \pm 0.002$ & $-0.015 \pm 0.003$ & $0.004 \pm 0.019$ \\
\hline
\end{tabular}

The shortwave atmospheric absorption change in the tropical regions is larger than in the Arctic regions. It is because $\mathrm{BC}$ burden in the tropics $\left(0.17 \mathrm{mg} \mathrm{m}^{-2}\right)$ is larger than in the Arctic $\left(0.09 \mathrm{mg} \mathrm{m}^{-2}\right)$. Strong absorption $\left(\sim 8 \mathrm{~W} \mathrm{~m}^{-2}\right)$ in the atmosphere is found in the land areas of southern Africa and South America and in the southeast Atlantic. The surface shortwave flux change in the Arctic is mostly from the TOA shortwave flux reduction due to the fire aerosol REaci, while the surface shortwave flux change in the tropics is mostly due to the fire $\mathrm{BC}$ absorption in the atmosphere.

The fire aerosols lead to the reduction of the global mean surface air temperature $\left(T_{\mathrm{S}}\right)$ by $0.03 \pm 0.03 \mathrm{~K}$, consistent with the reduction of shortwave fluxes at TOA and at the surface. The largest surface cooling is found in the Arctic and tropical regions by up to $0.6 \mathrm{~K}$. The cooling of the Arctic is related to the strong fire aerosol REaci, while the cooling in the tropics is mainly from the surface shortwave flux reduction due to the fire $\mathrm{BC}$ absorption. The $T_{\mathrm{S}}$ change in the ocean areas is very small since the SST is prescribed in our simulations.

The global mean total precipitation is reduced by $0.010 \pm 0.002 \mathrm{~mm} \mathrm{day}^{-1}$ due to all fire aerosols (Table 2). Unlike the $T_{\mathrm{S}}$ change, the precipitation reduction in the tropics $\left(0.016 \pm 0.01 \mathrm{~mm} \mathrm{day}^{-1}\right)$ is much larger than in the Arctic $\left(0.001 \pm 0.02 \mathrm{~mm} \mathrm{day}^{-1}\right.$, not statistically significant $)$. The reduction in the tropics is mainly from the large-scale precipitation decrease $\left(0.015 \pm 0.003 \mathrm{~mm} \mathrm{day}^{-1}\right)$. The net decrease in convective precipitation is very small in the tropics (0.001 $\pm 0.009 \mathrm{~mm} \mathrm{day}^{-1}$, not statistically significant), as the convective precipitation significantly decreases near the equator and increases in the regions away from the equator, partly consistent with the results of Tosca et al. (2013). The precipitation reduction in southern Africa is consistent with the recent findings of Hodnebrog et al. (2016). The shortwave flux reduction at the surface leads to a stabilization of the atmospheric boundary layer and a suppression of convection near the equator. The strong atmospheric absorption by fire $\mathrm{BC}$ leads to the reduction of low-level clouds and large-scale precipitation in the tropics. Both effects lead to a significant reduction of total precipitation near the equator. The precipitation decrease in the $\mathrm{NH}$ high latitudes is mainly from the reduction of convective precipitation. We note that the temperature and (especially) precipitation changes reported here do not represent the complete impact of fire aerosols, since the SSTs are fixed in our simulations. Fully coupled atmosphere and ocean models will be used to further investigate the impact of fire aerosols.

Figure 12 shows the changes of $T_{\mathrm{s}}$, total precipitation, cloud LWP and low-level cloud cover in the boreal summer due to all fire aerosols. The $T_{\mathrm{s}}$ is reduced by more than $1 \mathrm{~K}$ in most of land areas around $60^{\circ} \mathrm{N}$. The maximum cooling (larger than $1.5 \mathrm{~K}$ ) is found in Eastern Siberia, Alaska and Canada. A decrease of total precipitation (by about $0.2 \mathrm{~mm} \mathrm{day}^{-1}$ ) is found in these regions. Accompanying the surface cooling and precipitation reduction, a significant increase of cloud LWP and low-level cloud cover is found there. This is a result of the indirect effect of fire aerosols in the land areas of the Arctic $\left(60\right.$ to $\left.90^{\circ} \mathrm{N}\right)$. The fire POM leads to the reduction of cloud droplet effective radius and the increase of cloud droplet number concentration, con- 
(a) FIRE-NOFIRE

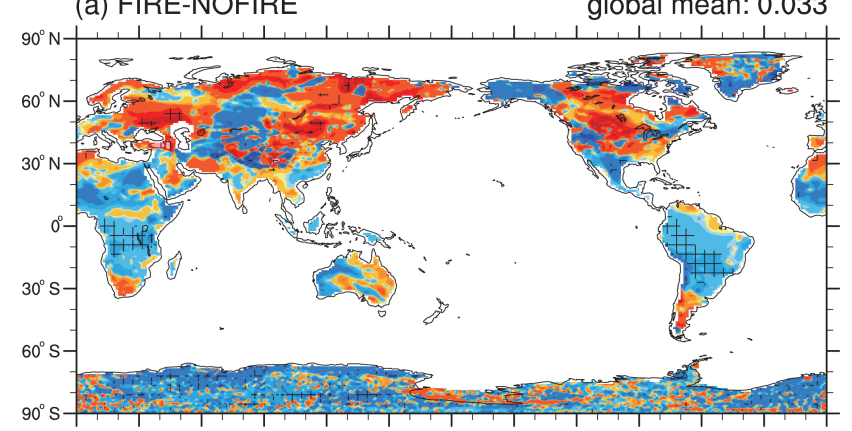

(b) SNICAR

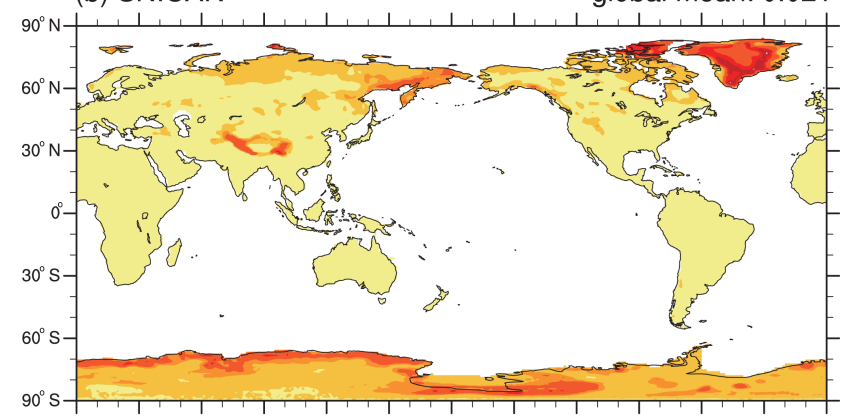

(c) SNICAR

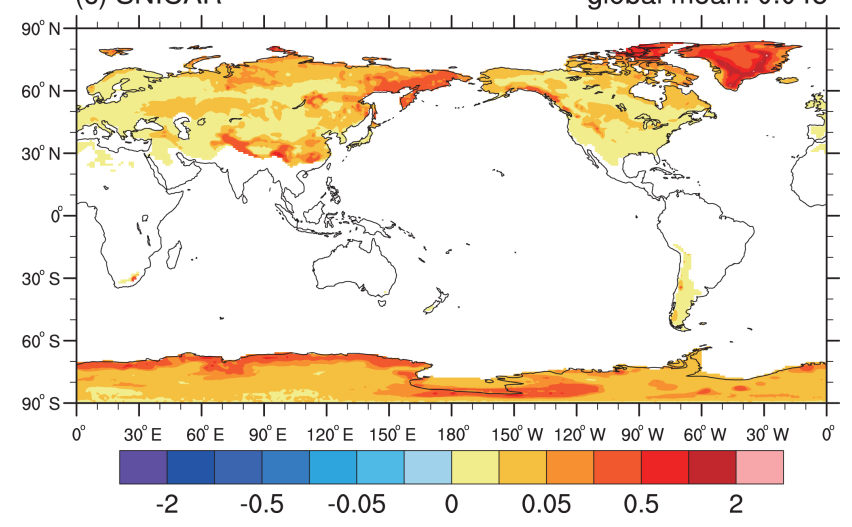

Figure 10. (a) Annual mean radiative effect due to surface-albedo changes (REsac, $\mathrm{W} \mathrm{m}^{-2}$ ) averaged over the period of 2003-2011 of all fire aerosols over land regions, and annual mean surface effect of fire BC-in-snow calculated from SNICAR averaged (b) over all times and (c) only when snow is present. The plus signs in (a) denote the regions where the radiative effect is statistically significant at the 0.1 level.

sistent with observed fire effects on clouds over Canada and the United States (Peng et al., 2002).

\section{Discussion and conclusions}

Although many studies have been conducted on the fire aerosols RE and RF (e.g., Bond et al., 2013; Myhre et al., 2013b; Ward et al., 2012; Tosca et al., 2013), the current estimations are still associated with large uncertainties. In this study, the fire aerosol RE (including REari, REaci and REsac) is calculated based on a new method from Ghan (2013).
In addition, the fire aerosol REari and fire BC-in-snow effect are diagnosed from an CESM experiment which tracks the open-fire BC and POM separately from fossil fuel and biofuel sources and compared with the estimates from the Ghan (2013) method.

The BC and POM burdens from open fires are largest in the tropical regions (southern Africa, South America and Southeast Asia) and in the NH middle to high latitudes (North of $45^{\circ} \mathrm{N}$ ) (northeast Asia, Alaska and Canada). Fire aerosols contribute 41 and $70 \%$ to the global burden of $\mathrm{BC}$ and POM, respectively. When being compared to the AERONET AOD and SSA data, modeled monthly AOD agrees with observations within a factor of 2 for most of the southern African and South American sites. The model underestimation of AOD is found in the South American sites near fire source regions, which is most obvious in the fire season (September and October). The model underestimates the observed AOD in the Arctic regions in both fire and nonfire seasons. The modeled SSA in southern Africa and South America is generally in agreement with observations, while the modeled SSA in the Arctic is lower.

The annual mean REari of all fire aerosols is $0.16 \pm 0.01 \mathrm{~W} \mathrm{~m}^{-2}$ and positive over most areas except in some land areas (e.g., southern Africa, northern Canada and Eastern Siberia). The annual maximum REari is found in the oceanic areas to the west of southern Africa $\left(5 \mathrm{~W} \mathrm{~m}^{-2}\right)$ and South America $\left(1.5 \mathrm{~W} \mathrm{~m}^{-2}\right)$. The positive REari over the land regions of southern Africa and South America is smaller, although the fire aerosol burdens are higher. The annual zonal mean REari in the Arctic regions can reach $0.43 \pm 0.028 \mathrm{~W} \mathrm{~m}^{-2}$ and is larger than in the tropical regions $\left(0.17 \pm 0.017 \mathrm{~W} \mathrm{~m}^{-2}\right)$, although the fire aerosol burden is higher in the tropics. The annual mean REari of fire $\mathrm{BC}$ is about $0.25 \pm 0.01 \mathrm{~W} \mathrm{~m}^{-2}$ and positive over the globe. Fire POM induces a weak negative REari globally $\left(-0.05 \mathrm{~W} \mathrm{~m}^{-2}\right)$ with the BBFFBF method and a small positive value $\left(0.04 \pm 0.01 \mathrm{~W} \mathrm{~m}^{-2}\right)$ with the Ghan (2013) method. The positive REari of fire POM is found over oceanic areas to the west of southern Africa and South America, North Pacific and polar regions where the low-level cloud coverage is large or the surface albedo is high.

The global annual mean REaci of all fire aerosols is $-0.70 \pm 0.05 \mathrm{~W} \mathrm{~m}^{-2}$ and the maximum effect is located in the ocean areas west of southern Africa and South America and land areas of the NH high latitudes. The maximum fire aerosol REaci occurs in the NH high latitudes in the boreal summer, which results from the large cloud LWP over the land areas and the low solar zenith angle. Associated with the strong indirect effects of fire aerosols in the Arctic summer, significant surface cooling, precipitation reduction, and low-level cloud cover increase are found in these regions.

Modeled BCS concentrations from the FIRE experiment are evaluated against observations in northern China and the Arctic and they generally agree with the observations for the 
(a) TOA solar flux

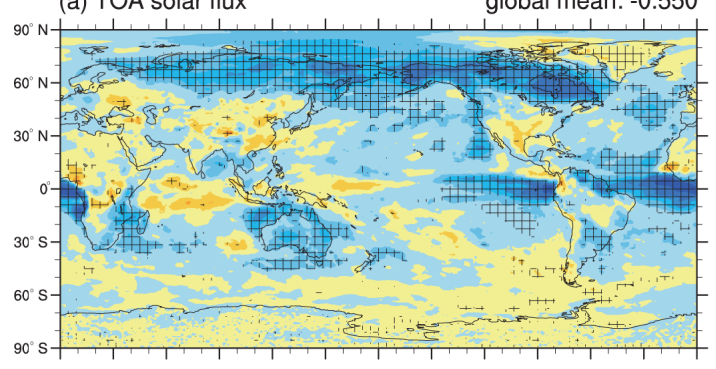

$\begin{array}{lllllllllllllll}-10 & -8 & -6 & -4 & -3 & -2 & -1 & 0 & 1 & 2 & 3 & 4 & 6 & 8 & 10\end{array}$

(c) Surface solar flux

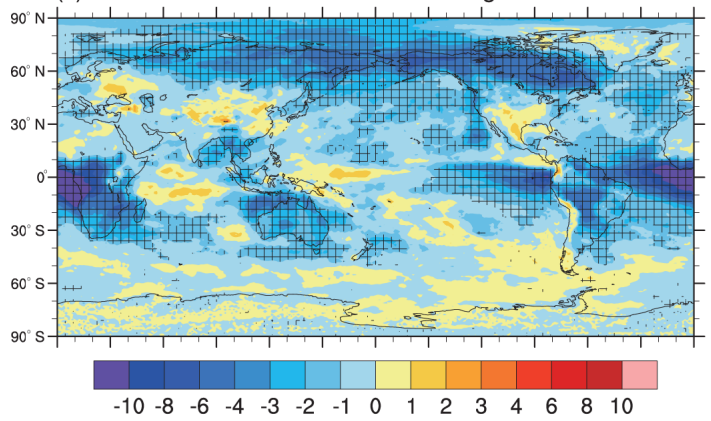

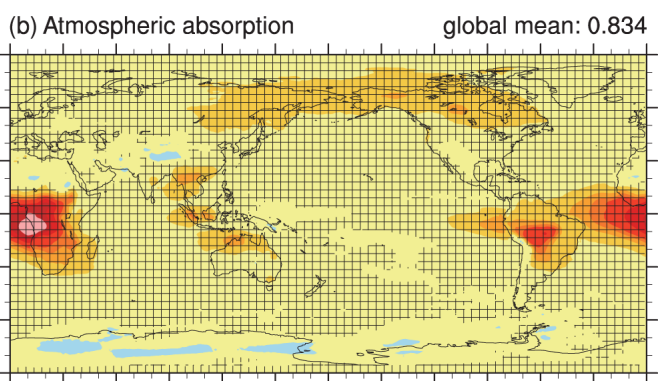

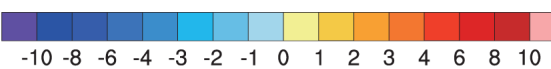

(d) TS
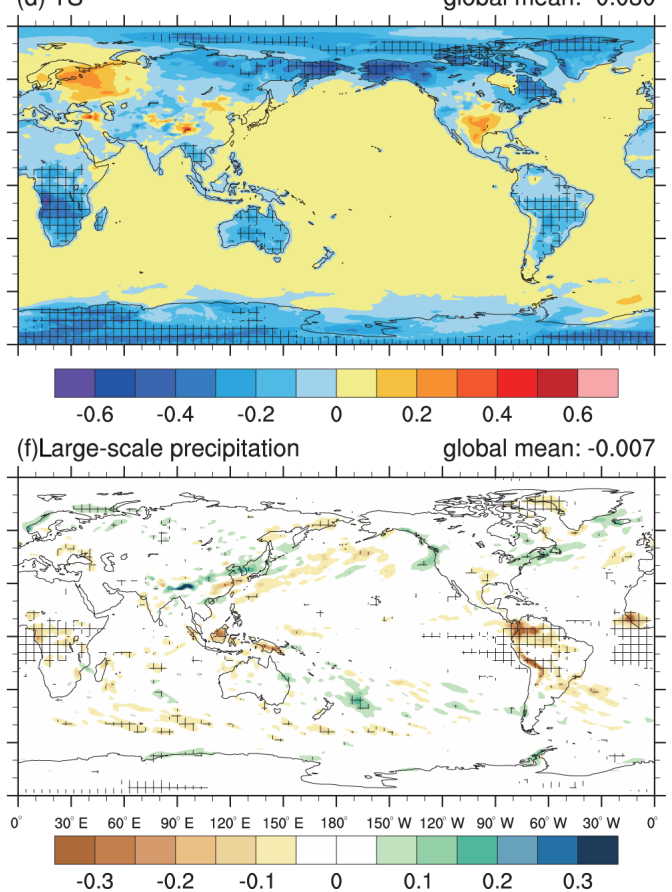

Figure 11. Annual mean net shortwave flux changes $\left(\mathrm{W} \mathrm{m}^{-2}\right)$ over the period of 2003-2011 (a) at top of the atmosphere, (b) in the atmosphere, (c) at the surface and changes of (d) surface air temperature $\left(T_{\mathrm{S}}, \mathrm{K}\right)$, (e) convective precipitation $\left(\mathrm{mm} \mathrm{d}^{-1}\right)$ and $(\mathbf{f})$ large-scale precipitation $\left(\mathrm{mm} \mathrm{d}^{-1}\right)$ due to all fire aerosols. The plus signs denote the regions where the change is statistically significant at the 0.1 level.

mean and median values in the Arctic regions. The high bias of modeled BCS concentrations in northern China may not result from the fire $\mathrm{BC}$ because differences in BCS concentrations between FIRE and NOFIRE experiments are very small in northern China. The global annual mean REsac is $0.03 \pm 0.10 \mathrm{~W} \mathrm{~m}^{-2}$ (statistically insignificant) with the maximum effect in spring $\left(0.12 \mathrm{~W} \mathrm{~m}^{-2}\right)$. The REsac is mainly due to the effect of fire BC deposit on snow $\left(0.02 \mathrm{~W} \mathrm{~m}^{-2}\right)$ diagnosed from SNICAR with the maximum effect as large as $0.06 \mathrm{~W} \mathrm{~m}^{-2}$ (when snow is present) in spring.

The fire aerosols reduce the global mean surface air temperature $\left(T_{\mathrm{S}}\right)$ by $0.03 \pm 0.03 \mathrm{~K}$ and precipitation by $0.01 \pm 0.002 \mathrm{~mm} \mathrm{day}^{-1}$. The maximum cooling $(\sim 1 \mathrm{~K})$ due to fire aerosols occurs around $60^{\circ} \mathrm{N}$ in boreal summer, and a suppression of precipitation $\left(\sim 0.1 \mathrm{~mm} \mathrm{day}^{-1}\right)$ is also found there. The strong cooling is a result of the strong indirect ef- fects $\left(-15 \mathrm{~W} \mathrm{~m}^{-2}\right)$ in the land areas of the Arctic regions (60 to $90^{\circ} \mathrm{N}$ ). A significant reduction of precipitation in southern Africa is also noticed. We note that these results are based on the simulations with fixed SSTs and may not represent the full climate responses.

In our study, the global radiative effect of fire aerosols is estimated from simulations performed with the 4-mode version modal aerosol module (MAM4) (Liu et al., 2016), daily fire emissions with prescribed vertical emission profiles, and higher model resolution $\left(0.9^{\circ}\right.$ by $\left.1.25^{\circ}\right)$ compared to earlier modeling studies of fire aerosols (Tosca et al., 2013; Ward et al., 2012). In their studies, the GFED fire aerosol emissions were increased by a factor of 1-3 depending on regions matching the observed AOD. In our study, we do not apply the scaling factor to the fire aerosol emissions. Our global annual mean REari of fire aerosols $\left(0.16 \pm 0.01 \mathrm{~W} \mathrm{~m}^{-2}\right)$ is, 
(a) TS(JJA)
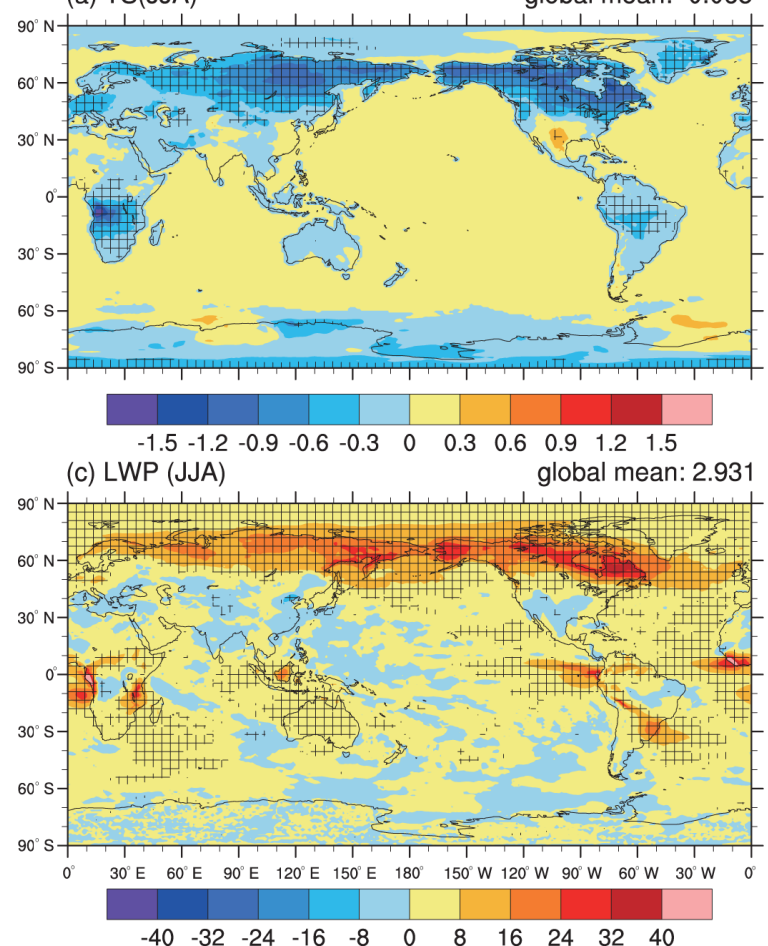
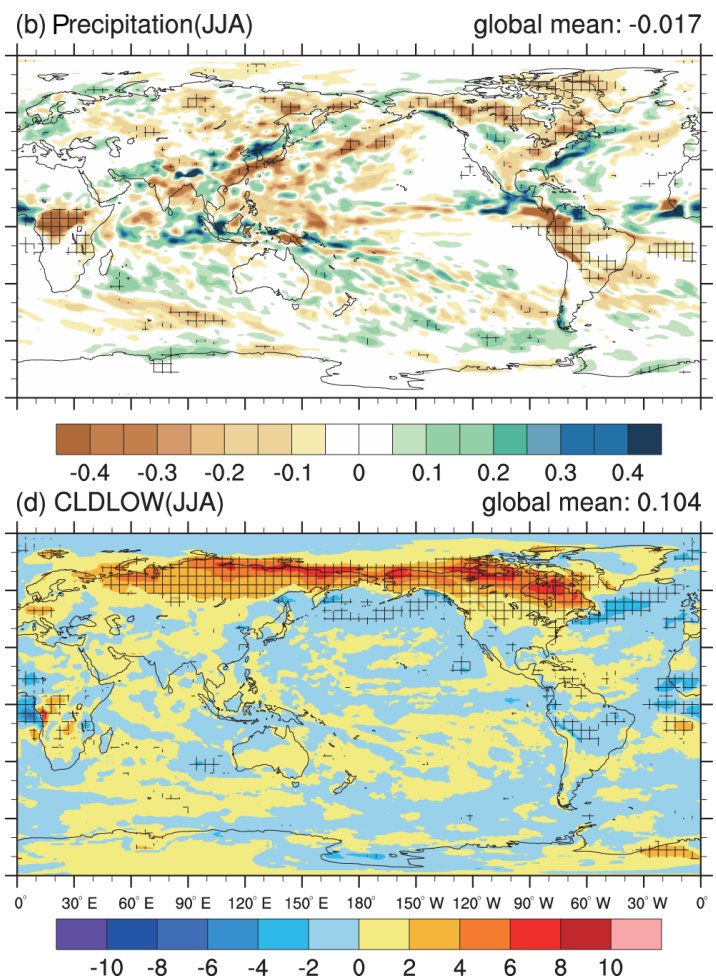

Figure 12. Changes in (a) surface air temperature $\left(T_{\mathrm{S}}\right.$, in $\left.\mathrm{K}\right)$, (b) total precipitation $\left(\mathrm{mm} \mathrm{d}^{-1}\right)$, (c) cloud liquid water path (LWP, in $\mathrm{g} \mathrm{m}{ }^{-2}$ ) and (d) low-level cloud cover (CLDLOW, in \%) due to all fire aerosols in the boreal summer (JJA) averaged for the period of $2003-2011$. The plus signs denote the regions where the change is statistically significant at the 0.1 level.

however, close to $0.18 \mathrm{~W} \mathrm{~m}^{-2}$ in Tosca et al. (2013) and $0.13 \mathrm{~W} \mathrm{~m}^{-2}$ in Ward et al. (2012). The similar fire aerosol REari from our study, which has smaller fire emissions than these previous studies can result from (1) the use of MAM4 in our study, which more realistically represents the external/internal mixing of BC with other soluble aerosol species; (2) the more accurate estimation of REari of fire aerosols in the presence of low-level clouds with the method by Ghan (2013) and (3) the inclusion of vertical emissions of fire aerosols, which allows more efficient transport of fire aerosols from sources. The REaci due to fire aerosols in our study $\left(-0.70 \pm 0.05 \mathrm{~W} \mathrm{~m}^{-2}\right)$ is smaller than $-1.64 \mathrm{~W} \mathrm{~m}^{-2}$ in Ward et al. (2012) due to the lower fire POM emissions used in this study compared to Ward et al. (2012).

We note that there are limitations and uncertainties with our study. The model still underestimates observed AODs (mostly within a factor of 2) at the sites predominantly influenced by biomass burning aerosols during the fire season, which implies that the fire aerosol RE can be stronger than estimated in this study. The RE estimates of fire POM and fire BC with the Ghan (2013) approach may not be accurate due to the internal mixing of co-emitted fire components (POM and $\mathrm{BC}$ ). In our simulations, sea ice is prescribed, thus the fire $\mathrm{BC}$ effect on sea ice albedo is not considered. The brown carbon component of POM (Feng et al., 2013) is not treated in the current CESM model, which may result in an underestimation of atmospheric absorption of fire aerosols.

\section{Data availability}

The fire emission data were obtained from the Global Fire Emissions Database (GFED, http://www.globalfiredata.org). The AERONET data were obtained from http://aeronet.gsfc. nasa.gov. Model outputs are available on request from the corresponding author. The source codes and model setups needed to repeat all simulations are also available upon request.

\section{The Supplement related to this article is available online at doi:10.5194/acp-16-14805-2016-supplement.}

Acknowledgements. This work is supported by the Office of Science of the US Department of Energy (DOE) as the NSFDOE-USDA Joint Earth System Modeling (EaSM) Program, the National Key Basic Research Program (973 Program) of China under Grant No. 2010CB428504, and the National Natural Science Foundation of China (NSFC) under Grant No. 41505062. The Pacific Northwest National Laboratory is operated for the 
DOE by the Battelle Memorial Institute under contract DEAC05-76RL01830. The authors would like to acknowledge the use of computational resources (ark:/85065/d7wd3xhc) at the NCAR-Wyoming Supercomputing Center provided by the National Science Foundation and the State of Wyoming, and supported by NCAR's Computational and Information Systems Laboratory. The fire emission data were obtained from the Global Fire Emissions Database (GFED, http://www.globalfiredata.org). The AERONET data were obtained from http://aeronet.gsfc.nasa.gov. We thank Xiangjun Shi for the help with processing the AERONET data.

Edited by: K. Tsigaridis

Reviewed by: two anonymous referees

\section{References}

Abel, S. J., Highwood, E. J., Haywood, J. M., and Stringer, M. A.: The direct radiative effect of biomass burning aerosols over southern Africa, Atmos. Chem. Phys., 5, 1999-2018, doi:10.5194/acp-5-1999-2005, 2005.

Ackerman, A. S., Toon, O. B., Stevens, D. E., Heymsfield, A. J., Ramanathan, V., and Welton, E. J.: Reduction of Tropical Cloudiness by Soot, Science, 288, 1042-1047, doi:10.1126/science.288.5468.1042, 2000.

Andreae, M. O. and Rosenfeld, D.: Aerosol-cloudprecipitation interactions. Part 1. The nature and sources of cloud-active aerosols, Earth-Sci. Rev., 89, 13-41, doi:10.1016/j.earscirev.2008.03.001, 2008.

Andreae, M. O., Rosenfeld, D., Artaxo, P., Costa, A. A., Frank, G. P., Longo, K. M., and Silva-Dias, M. A. F.: Smoking Rain Clouds over the Amazon, Science, 303, 1337-1342, doi:10.1126/science.1092779, 2004.

Bistinas, I., Harrison, S. P., Prentice, I. C., and Pereira, J. M. C.: Causal relationships versus emergent patterns in the global controls of fire frequency, Biogeosciences, 11, 5087-5101, doi:10.5194/bg-11-5087-2014, 2014.

Bond, T. C., Doherty, S. J., Fahey, D. W., Forster, P. M., Berntsen, T., DeAngelo, B. J., Flanner, M. G., Ghan, S., Karcher, B., Koch, D., Kinne, S., Kondo, Y., Quinn, P. K., Sarofim, M. C., Schultz, M. G., Schulz, M., Venkataraman, C., Zhang, H., Zhang, S., Bellouin, N., Guttikunda, S. K., Hopke, P. K., Jacobson, M. Z., Kaiser, J. W., Klimont, Z., Lohmann, U., Schwarz, J. P., Shindell, D., Storelvmo, T., Warren, S. G., and Zender, C. S.: Bounding the role of black carbon in the climate system: A scientific assessment, J. Geophys. Res.-Atmos., 118, 5380-5552, doi:10.1002/Jgrd.50171, 2013.

Boucher, O. and Tanré, D.: Estimation of the aerosol perturbation to the Earth's Radiative Budget over oceans using POLDER satellite aerosol retrievals, Geophys. Res. Lett., 27, 1103-1106, doi:10.1029/1999GL010963, 2000.

Bowman, D. M. J. S., Balch, J. K., Artaxo, P., Bond, W. J., Carlson, J. M., Cochrane, M. A., D’Antonio, C. M., DeFries, R. S., Doyle, J. C., Harrison, S. P., Johnston, F. H., Keeley, J. E., Krawchuk, M. A., Kull, C. A., Marston, J. B., Moritz, M. A., Prentice, I. C., Roos, C. I., Scott, A. C., Swetnam, T. W., van der Werf, G. R., and Pyne, S. J.: Fire in the Earth System, Science, 324, 481-484, doi:10.1126/science.1163886, 2009.
Carslaw, K. S., Boucher, O., Spracklen, D. V., Mann, G. W., Rae, J. G. L., Woodward, S., and Kulmala, M.: A review of natural aerosol interactions and feedbacks within the Earth system, Atmos. Chem. Phys., 10, 1701-1737, doi:10.5194/acp-10-17012010, 2010.

Chakrabarty, R. K., Beres, N. D., Moosmüller, H., China, S., Mazzoleni, C., Dubey, M. K., Liu, L., and Mishchenko, M. I.: Soot superaggregates from flaming wildfires and their direct radiative forcing, Scientific Reports, 4, 5508, doi:10.1038/srep05508, 2014.

Ciais, P., Sabine, C., Bala, G., Bopp, L., Brovkin, V., Canadell, J., Chhabra, A., DeFries, R., Galloway, J., Heimann, M., Jones, C., Le Quéré, C., Myneni, R. B., Piao, S., and Thornton, P.: Carbon and Other Biogeochemical Cycles, in: Climate Change 2013: The Physical Science Basis. Contribution of Working Group I to the Fifth Assessment Report of the Intergovernmental Panel on Climate Change, edited by: Stocker, T. F., Qin, D., Plattner, G.K., Tignor, M., Allen, S. K., Boschung, J., Nauels, A., Xia, Y., Bex, V., and Midgley, P. M., Cambridge University Press, Cambridge, UK and New York, NY, USA, 465-570, 2013.

Cohen, J. B. and Wang, C.: Estimating global black carbon emissions using a top-down Kalman Filter approach, J. Geophys. Res.-Atmos., 119, 2013JD019912, doi:10.1002/2013JD019912, 2014.

Dentener, F., Kinne, S., Bond, T., Boucher, O., Cofala, J., Generoso, S., Ginoux, P., Gong, S., Hoelzemann, J. J., Ito, A., Marelli, L., Penner, J. E., Putaud, J.-P., Textor, C., Schulz, M., van der Werf, G. R., and Wilson, J.: Emissions of primary aerosol and precursor gases in the years 2000 and 1750 prescribed data-sets for AeroCom, Atmos. Chem. Phys., 6, 4321-4344, doi:10.5194/acp-64321-2006, 2006.

Doherty, S. J., Warren, S. G., Grenfell, T. C., Clarke, A. D., and Brandt, R. E.: Light-absorbing impurities in Arctic snow, Atmos. Chem. Phys., 10, 11647-11680, doi:10.5194/acp-1011647-2010, 2010.

Feng, Y., Ramanathan, V., and Kotamarthi, V. R.: Brown carbon: a significant atmospheric absorber of solar radiation?, Atmos. Chem. Phys., 13, 8607-8621, doi:10.5194/acp-13-8607-2013, 2013.

Flanner, M. G. and Zender, C. S.: Snowpack radiative heating: Influence on Tibetan Plateau climate, Geophys. Res. Lett., 32, L06501, L06501, doi:10.1029/2004g1022076, 2005.

Flanner, M. G., Zender, C. S., Randerson, J. T., and Rasch, P. J.: Present-day climate forcing and response from black carbon in snow, J. Geophys. Res.-Atmos., 112, D11202, doi:10.1029/2006JD008003, 2007.

Flanner, M. G., Zender, C. S., Hess, P. G., Mahowald, N. M., Painter, T. H., Ramanathan, V., and Rasch, P. J.: Springtime warming and reduced snow cover from carbonaceous particles, Atmos. Chem. Phys., 9, 2481-2497, doi:10.5194/acp-9-24812009, 2009.

Forster, P., Ramaswamy, V., Artaxo, P., Berntsen, T., Betts, R., Fahey, D. W., Haywood, J., Lean, J., Lowe, D. C., Myhre, G., Nganga, J., Prinn, R., Raga, G., Schulz, M., and Van Dorland, R.: Changes in Atmospheric Constituents and in Radiative Forcing, in: Climate Change 2007: The Physical Science Basis. Contribution of Working Group I to the Fourth Assessment Report of the Intergovernmental Panel on Climate Change, edited by: Solomon, S., Qin, D., Manning, M., Chen, Z., Marquis, M., Av- 
eryt, K. B., Tignor, M., and Miller, H. L., Cambridge University Press, Cambridge, UK and New York, NY, USA, 2007.

Ghan, S. J.: Technical Note: Estimating aerosol effects on cloud radiative forcing, Atmos. Chem. Phys., 13, 9971-9974, doi:10.5194/acp-13-9971-2013, 2013.

Ghan, S. J., Liu, X., Easter, R. C., Zaveri, R., Rasch, P. J., Yoon, J.H., and Eaton, B.: Toward a Minimal Representation of Aerosols in Climate Models: Comparative Decomposition of Aerosol Direct, Semidirect, and Indirect Radiative Forcing, J. Climate, 25, 6461-6476, doi:10.1175/JCLI-D-11-00650.1, 2012.

Giglio, L., Randerson, J. T., and van der Werf, G. R.: Analysis of daily, monthly, and annual burned area using the fourthgeneration global fire emissions database (GFED4), J. Geophys. Res.-Biogeo., 118, 317-328, doi:10.1002/jgrg.20042, 2013.

Hansen, J., Sato, M., Ruedy, R., Nazarenko, L., Lacis, A., Schmidt, G. A., Russell, G., Aleinov, I., Bauer, M., Bauer, S., Bell, N., Cairns, B., Canuto, V., Chandler, M., Cheng, Y., Del Genio, A., Faluvegi, G., Fleming, E., Friend, A., Hall, T., Jackman, C., Kelley, M., Kiang, N., Koch, D., Lean, J., Lerner, J., Lo, K., Menon, S., Miller, R., Minnis, P., Novakov, T., Oinas, V., Perlwitz, J., Perlwitz, J., Rind, D., Romanou, A., Shindell, D., Stone, P., Sun, S., Tausnev, N., Thresher, D., Wielicki, B., Wong, T., Yao, M., and Zhang, S.: Efficacy of climate forcings, J. Geophys. Res.Atmos., 110, D18104, doi:10.1029/2005JD005776, 2005.

Heald, C. L., Ridley, D. A., Kroll, J. H., Barrett, S. R. H., CadyPereira, K. E., Alvarado, M. J., and Holmes, C. D.: Contrasting the direct radiative effect and direct radiative forcing of aerosols, Atmos. Chem. Phys., 14, 5513-5527, doi:10.5194/acp-14-55132014, 2014.

Hodnebrog, Ø., Myhre, G., Forster, P. M., Sillmann, J., and Samset, B. H.: Local biomass burning is a dominant cause of the observed precipitation reduction in southern Africa, Nat. Commun., 7, 11236, doi:10.1038/ncomms11236, 2016.

Jacobson, M. Z.: Climate response of fossil fuel and biofuel soot, accounting for soot's feedback to snow and sea ice albedo and emissivity, J. Geophys. Res.-Atmos., 109, D21201, doi:10.1029/2004JD004945, 2004.

Jiang, Y., Liu, X., Yang, X.-Q., and Wang, M.: A numerical study of the effect of different aerosol types on East Asian summer clouds and precipitation, Atmos. Environ., 70, 51-63, doi:10.1016/j.atmosenv.2012.12.039, 2013.

Jiang, Y., Yang, X.-Q., and Liu, X.: Seasonality in anthropogenic aerosol effects on East Asian climate simulated with CAM5, J. Geophys. Res.-Atmos., 120, 2015JD023451, doi:10.1002/2015JD023451, 2015.

Jones, A., Haywood, J. M., and Boucher, O.: Aerosol forcing, climate response and climate sensitivity in the Hadley Centre climate model, J. Geophys. Res.-Atmos., 112, D20211, doi:10.1029/2007JD008688, 2007.

Kaiser, J. W., Heil, A., Andreae, M. O., Benedetti, A., Chubarova, N., Jones, L., Morcrette, J.-J., Razinger, M., Schultz, M. G., Suttie, M., and van der Werf, G. R.: Biomass burning emissions estimated with a global fire assimilation system based on observed fire radiative power, Biogeosciences, 9, 527-554, doi:10.5194/bg-9-527-2012, 2012.

Keywood, M., Kanakidou, M., Stohl, A., Dentener, F., Grassi, G., Meyer, C. P., Torseth, K., Edwards, D., Thompson, A. M., Lohmann, U., and Burrows, J.: Fire in the Air: Biomass Burn- ing Impacts in a Changing Climate, Crit. Rev. Env. Sci. Tec., 43, 40-83, doi:10.1080/10643389.2011.604248, 2011.

Koch, D. and Del Genio, A. D.: Black carbon semi-direct effects on cloud cover: review and synthesis, Atmos. Chem. Phys., 10, 7685-7696, doi:10.5194/acp-10-7685-2010, 2010.

Koch, D., Menon, S., Del Genio, A., Ruedy, R., Alienov, I., and Schmidt, G. A.: Distinguishing Aerosol Impacts on Climate over the Past Century, J. Climate, 22, 2659-2677, doi:10.1175/2008JCLI2573.1, 2009.

Koch, D., Balkanski, Y., Bauer, S. E., Easter, R. C., Ferrachat, S., Ghan, S. J., Hoose, C., Iversen, T., Kirkevåg, A., Kristjansson, J. E., Liu, X., Lohmann, U., Menon, S., Quaas, J., Schulz, M., Seland, Ø., Takemura, T., and Yan, N.: Soot microphysical effects on liquid clouds, a multi-model investigation, Atmos. Chem. Phys., 11, 1051-1064, doi:10.5194/acp-11-1051-2011, 2011.

Koren, I., Kaufman, Y. J., Rosenfeld, D., Remer, L. A., and Rudich, Y.: Aerosol invigoration and restructuring of Atlantic convective clouds, Geophys. Res. Lett., 32, L14828, doi:10.1029/2005GL023187, 2005.

Lamarque, J.-F., Bond, T. C., Eyring, V., Granier, C., Heil, A., Klimont, Z., Lee, D., Liousse, C., Mieville, A., Owen, B., Schultz, M. G., Shindell, D., Smith, S. J., Stehfest, E., Van Aardenne, J., Cooper, O. R., Kainuma, M., Mahowald, N., McConnell, J. R., Naik, V., Riahi, K., and van Vuuren, D. P.: Historical (1850-2000) gridded anthropogenic and biomass burning emissions of reactive gases and aerosols: methodology and application, Atmos. Chem. Phys., 10, 7017-7039, doi:10.5194/acp10-7017-2010, 2010.

Liu, X., Penner, J. E., Das, B., Bergmann, D., Rodriguez, J. M., Strahan, S., Wang, M., and Feng, Y.: Uncertainties in global aerosol simulations: Assessment using three meteorological datasets, J. Geophys. Res., 112, D11212, doi:10.1029/2006JD008216, 2007.

Liu, X., Easter, R. C., Ghan, S. J., Zaveri, R., Rasch, P., Shi, X., Lamarque, J.-F., Gettelman, A., Morrison, H., Vitt, F., Conley, A., Park, S., Neale, R., Hannay, C., Ekman, A. M. L., Hess, P., Mahowald, N., Collins, W., Iacono, M. J., Bretherton, C. S., Flanner, M. G., and Mitchell, D.: Toward a minimal representation of aerosols in climate models: description and evaluation in the Community Atmosphere Model CAM5, Geosci. Model Dev., 5, 709-739, doi:10.5194/gmd-5-709-2012, 2012.

Liu, X., Ma, P.-L., Wang, H., Tilmes, S., Singh, B., Easter, R. C., Ghan, S. J., and Rasch, P. J.: Description and evaluation of a new four-mode version of the Modal Aerosol Module (MAM4) within version 5.3 of the Community Atmosphere Model, Geosci. Model Dev., 9, 505-522, doi:10.5194/gmd-9505-2016, 2016.

Liu, Y.: Atmospheric response and feedback to radiative forcing from biomass burning in tropical South America, Agr. Forest Meteorol., 133, 40-53, doi:10.1016/j.agrformet.2005.03.011, 2005.

Liu, Y., Goodrick, S., and Heilman, W.: Wildland fire emissions, carbon, and climate: Wildfire-climate interactions, Forest Ecol. Manage., 317, 80-96, doi:10.1016/j.foreco.2013.02.020, 2014.

Lu, Z. and Sokolik, I. N.: The effect of smoke emission amount on changes in cloud properties and precipitation: A case study of Canadian boreal wildfires of 2007, J. Geophys. Res.Atmospheres, 118, 2013JD019860, doi:10.1002/2013JD019860, 2013. 
Ma, P.-L., Rasch, P. J., Wang, H., Zhang, K., Easter, R. C., Tilmes, S., Fast, J. D., Liu, X., Yoon, J.-H., and Lamarque, J.-F.: The role of circulation features on black carbon transport into the Arctic in the Community Atmosphere Model version 5 (CAM5), J. Geophys. Res.-Atmos., 118, 4657-4669, 2013.

Ma, P.-L., Rasch, P. J., Fast, J. D., Easter, R. C., Gustafson Jr., W. I., Liu, X., Ghan, S. J., and Singh, B.: Assessing the CAM5 physics suite in the WRF-Chem model: implementation, resolution sensitivity, and a first evaluation for a regional case study, Geosci. Model Dev., 7, 755-778, doi:10.5194/gmd-7-755-2014, 2014.

Ma, P.-L., Rasch, P. J., Wang, M., Wang, H., Ghan, S. J., Easter, R. C., Gustafson Jr., W. I., Liu, X., Zhang, Y., and Ma, H.-Y.: How does increasing horizontal resolution in a global climate model improve the simulation of aerosol-cloud interactions?, Geophys. Res. Lett., 42, 5058-5065, doi:10.1002/2015GL064183, 2015.

Marlon, J. R., Bartlein, P. J., Walsh, M. K., Harrison, S. P., Brown, K. J., Edwards, M. E., Higuera, P. E., Power, M. J., Anderson, R. S., Briles, C., Brunelle, A., Carcaillet, C., Daniels, M., Hu, F. S., Lavoie, M., Long, C., Minckley, T., Richard, P. J. H., Scott, A. C., Shafer, D. S., Tinner, W., Umbanhowar, C. E., and Whitlock, C.: Wildfire responses to abrupt climate change in North America, P. Natl. Acad. Sci., 106, 2519-2524, doi:10.1073/pnas.0808212106, 2009.

Min M. and Zhang Z.: On the influence of cloud fraction diurnal cycle and sub-grid cloud optical thickness variability on all-sky direct aerosol radiative forcing, J. Quant. Spectros. Ra., 142, 2536, doi:10.1016/j.jqsrt.2014.03.014, 2014.

Morrison, H. and Gettelman, A.: A New Two-Moment Bulk Stratiform Cloud Microphysics Scheme in the Community Atmosphere Model, Version 3 (CAM3). Part I: Description and Numerical Tests, J. Climate, 21, 3642-3659, doi:10.1175/2008JCLI2105.1, 2008.

Myhre, G. and Samset, B. H.: Standard climate models radiation codes underestimate black carbon radiative forcing, Atmos. Chem. Phys., 15, 2883-2888, doi:10.5194/acp-15-2883-2015, 2015.

Myhre, G., Samset, B. H., Schulz, M., Balkanski, Y., Bauer, S., Berntsen, T. K., Bian, H., Bellouin, N., Chin, M., Diehl, T., Easter, R. C., Feichter, J., Ghan, S. J., Hauglustaine, D., Iversen, T., Kinne, S., Kirkevåg, A., Lamarque, J.-F., Lin, G., Liu, X., Lund, M. T., Luo, G., Ma, X., van Noije, T., Penner, J. E., Rasch, P. J., Ruiz, A., Seland, Ø., Skeie, R. B., Stier, P., Takemura, T., Tsigaridis, K., Wang, P., Wang, Z., Xu, L., Yu, H., Yu, F., Yoon, J.-H., Zhang, K., Zhang, H., and Zhou, C.: Radiative forcing of the direct aerosol effect from AeroCom Phase II simulations, Atmos. Chem. Phys., 13, 1853-1877, doi:10.5194/acp-13-18532013, 2013a.

Myhre, G., Shindell, D., Brè̀on, F.-M., Collins, W., Fuglestvedt, J., Huang, J., Koch, D., Lamarque, J.-F., Lee, D., Mendoza, B., Nakajima, T., Robock, A., Stephens, G., Takemura, T., and Zhang, H.: Anthropogenic and Natural Radiative Forcing, in: Climate Change 2013: The Physical Science Basis. Contribution of Working Group I to the Fifth Assessment Report of the Intergovernmental Panel on Climate Change, edited by: Stocker, T. F., Qin, D., Plattner, G.-K., Tignor, M., Allen, S. K., Boschung, J., Nauels, A., Xia, Y., Bex, V., and Midgley, P. M., Cambridge University Press, Cambridge, United Kingdom and New York, NY, USA, 659-740, 2013b.
Neale, R. B., Chen, C.-C., Gettelman, A., Lauritzen, P. H., Park, S., Williamson, D. L., Conley, A. J., Garcia, R., Kinnison, D., Lamarque, J.-F., Marsh, D., Mills, M., Smith, A. K., Tilmes, S., Vitt, F., Cameron-Smith, P., Collins,W. D., Iacono, M. J., Easter, R. C., Ghan, S. J., Liu, X., Rasch, P. J., and Taylor, M. A.: Description of the NCAR Community Atmosphere Model (CAM 5.0), NCAR/TN-486+ STR, available at: http://www.cesm.ucar.edu/models/cesm1.0/ cam/docs/description/cam5_desc.pdf (last access: 28 November 2016), 2012.

Oleson, K. W., Lawrence, D. M., Bonan, G. B., Flanner, M. G., Kluzek, E., Lawrence, P. J., Levis, S., Swenson, S. C., Thornton, P. E., Dai, A., Decker, M., DIckinson, R., Feddema, J., Heald, C. L., Hoffman, F., Lamarque, J. F., Mahowald, N., Niu, G.-Y., Qian, T., Randerson, J., Running, S., Sakaguchi, K., Slater, A., Stockli, R., Wang, A., Yang, Z.-L., Zeng, X., and Zeng, X.: Technical description of version 4.0 of the Community Land Model, NCAR Tech. Note NCAR/TN-478+STR, doi:10.5065/D6FB50WZ, 2010.

Peng, Y., Lohmann, U., Leaitch, R., Banic, C., and Couture, M.: The cloud albedo-cloud droplet effective radius relationship for clean and polluted clouds from RACE and FIRE.ACE, J. Geophys. Res.-Atmos., 107, AAC 1-1-AAC 1-6, doi:10.1029/2000JD000281, 2002.

Qian, Y., Gong, D., Fan, J., Leung, L. R., Bennartz, R., Chen, D., and Wang, W.: Heavy pollution suppresses light rain in China: Observations and modeling, J. Geophys. Res.-Atmos., 114, D00K02, doi:10.1029/2008JD011575, 2009.

Qian, Y., Flanner, M. G., Leung, L. R., and Wang, W.: Sensitivity studies on the impacts of Tibetan Plateau snowpack pollution on the Asian hydrological cycle and monsoon climate, Atmos. Chem. Phys., 11, 1929-1948, doi:10.5194/acp-11-19292011, 2011.

Qian, Y., Wang, H., Zhang, R., Flanner, M. G., and Rasch, P. J.: A sensitivity study on modeling black carbon in snow and its radiative forcing over the Arctic and Northern China, Environ. Res. Lett., 9, 064001, doi:10.1088/1748-9326/9/6/064001, 2014

Qian, Y., Yasunari, T. J., Doherty, S. J., Flanner, M. G., Lau, W. K. M., Ming, J., Wang, H., Wang, M., Warren, S. G., and Zhang, R.: Light-absorbing particles in snow and ice: Measurement and modeling of climatic and hydrological impact, Adv. Atmos. Sci., 32, 64-91, doi:10.1007/s00376-014-0010-0, 2015.

Quinn, P. K., Bates, T. S., Baum, E., Doubleday, N., Fiore, A. M., Flanner, M., Fridlind, A., Garrett, T. J., Koch, D., Menon, S., Shindell, D., Stohl, A., and Warren, S. G.: Short-lived pollutants in the Arctic: their climate impact and possible mitigation strategies, Atmos. Chem. Phys., 8, 1723-1735, doi:10.5194/acp8-1723-2008, 2008.

Randerson, J. T., Liu, H., Flanner, M. G., Chambers, S. D., Jin, Y., Hess, P. G., Pfister, G., Mack, M. C., Treseder, K. K., Welp, L. R., Chapin, F. S., Harden, J. W., Goulden, M. L., Lyons, E., Neff, J. C., Schuur, E. A. G., and Zender, C. S.: The Impact of Boreal Forest Fire on Climate Warming, Science, 314, 1130-1132, 2006.

Rypdal, K., Rive, N., Berntsen, T. K., Klimont, Z., Mideksa, T. K., Myhre, G., and Skeie, R. B.: Costs and global impacts of black carbon abatement strategies, Tellus B, 61, 625-641, doi:10.1111/j.1600-0889.2009.00430.x, 2009. 
Sena, E. T. and Artaxo, P.: A novel methodology for largescale daily assessment of the direct radiative forcing of smoke aerosols, Atmos. Chem. Phys., 15, 5471-5483, doi:10.5194/acp15-5471-2015, 2015.

Skeie, R. B., Berntsen, T., Myhre, G., Pedersen, C. A., Ström, J., Gerland, S., and Ogren, J. A.: Black carbon in the atmosphere and snow, from pre-industrial times until present, Atmos. Chem. Phys., 11, 6809-6836, doi:10.5194/acp-11-6809-2011, 2011.

Sommers, W. T., Loehman, R. A., and Hardy, C. C.: Wildland fire emissions, carbon, and climate: Science overview and knowledge needs, Forest Ecol. Manage., 317, 1-8, doi:10.1016/j.foreco.2013.12.014, 2014.

Stohl, A., Klimont, Z., Eckhardt, S., Kupiainen, K., Shevchenko, V. P., Kopeikin, V. M., and Novigatsky, A. N.: Black carbon in the Arctic: the underestimated role of gas flaring and residential combustion emissions, Atmos. Chem. Phys., 13, 8833-8855, doi:10.5194/acp-13-8833-2013, 2013.

Tosca, M. G., Randerson, J. T., and Zender, C. S.: Global impact of smoke aerosols from landscape fires on climate and the Hadley circulation, Atmos. Chem. Phys., 13, 5227-5241, doi:10.5194/acp-13-5227-2013, 2013.

Tosca, M. G., Diner, D. J., Garay, M. J., and Kalashnikova, O. V.: Observational evidence of fire-driven reduction of cloud fraction in tropical Africa, J. Geophys. Res.-Atmos., 119, 8418-8432, doi:10.1002/2014JD021759, 2014.

van der Werf, G. R., Dempewolf, J., Trigg, S. N., Randerson, J. T., Kasibhatla, P. S., Giglio, L., Murdiyarso, D., Peters, W., Morton, D. C., Collatz, G. J., Dolman, A. J., and DeFries, R. S.: Climate regulation of fire emissions and deforestation in equatorial Asia, P. Natl. Acad. Sci. USA, 105, 20350-20355, doi:10.1073/pnas.0803375105, 2008.

van der Werf, G. R., Randerson, J. T., Giglio, L., Collatz, G. J., Mu, M., Kasibhatla, P. S., Morton, D. C., DeFries, R. S., Jin, Y., and van Leeuwen, T. T.: Global fire emissions and the contribution of deforestation, savanna, forest, agricultural, and peat fires (19972009), Atmos. Chem. Phys., 10, 11707-11735, doi:10.5194/acp10-11707-2010, 2010.

Voulgarakis, A. and Field, R. D.: Fire influences on atmospheric composition, air quality and climate, Current Pollution Reports, 1, 70-81, doi:10.1007/s40726-015-0007-z, 2015.
Wang, H., Easter, R. C., Rasch, P. J., Wang, M., Liu, X., Ghan, S. J., Qian, Y., Yoon, J.-H., Ma, P.-L., and Vinoj, V.: Sensitivity of remote aerosol distributions to representation of cloud-aerosol interactions in a global climate model, Geosci. Model Dev., 6, 765-782, doi:10.5194/gmd-6-765-2013, 2013a.

Wang, X., Doherty, S. J., and Huang, J.: Black carbon and other light-absorbing impurities in snow across Northern China, J. Geophys. Res.-Atmos., 118, 1471-1492, doi:10.1029/2012JD018291, 2013b.

Ward, D. S., Kloster, S., Mahowald, N. M., Rogers, B. M., Randerson, J. T., and Hess, P. G.: The changing radiative forcing of fires: global model estimates for past, present and future, Atmos. Chem. Phys., 12, 10857-10886, doi:10.5194/acp12-10857-2012, 2012.

Westerling, A. L., Hidalgo, H. G., Cayan, D. R., and Swetnam, T. W.: Warming and earlier spring increase western U.S. forest wildfire activity, Science, 313, 940-943, doi:10.1126/science.1128834, 2006.

Wiedinmyer, C., Akagi, S. K., Yokelson, R. J., Emmons, L. K., AlSaadi, J. A., Orlando, J. J., and Soja, A. J.: The Fire INventory from NCAR (FINN): a high resolution global model to estimate the emissions from open burning, Geosci. Model Dev., 4, 625641, doi:10.5194/gmd-4-625-2011, 2011.

Zhang, Y., Fu, R., Yu, H., Qian, Y., Dickinson, R., Silva Dias, M. A. F., da Silva Dias, P. L., and Fernandes, K.: Impact of biomass burning aerosol on the monsoon circulation transition over Amazonia, Geophys. Res. Lett., 36, L10814, doi:10.1029/2009GL037180, 2009.

Zhang, Z., Meyer, K., Platnick, S., Oreopoulos, L., Lee, D., and Yu, H.: A novel method for estimating shortwave direct radiative effect of above-cloud aerosols using CALIOP and MODIS data, Atmos. Meas. Tech., 7, 1777-1789, doi:10.5194/amt-71777-2014, 2014.

Zhang, Z., Meyer, K., Yu, H., Platnick, S., Colarco, P., Liu, Z., and Oreopoulos, L.: Shortwave direct radiative effects of above-cloud aerosols over global oceans derived from 8 years of CALIOP and MODIS observations, Atmos. Chem. Phys., 16, 2877-2900, doi:10.5194/acp-16-2877-2016, 2016. 